\title{
Nickel-titanium instruments in endodontics: a concise review of the state of the art
}

\section{Giulio GAVINI(a) \\ Marcelo dos SANTOS(a) \\ Celso Luis CALDEIRA ${ }^{(a)}$ \\ Manoel Eduardo de Lima \\ MACHADO(a) \\ Laila Gonzales FREIRE(a) \\ Elaine Faga IGLECIAS(a) \\ Ove Andrea PETERS(b) \\ George Táccio de Miranda \\ CANDEIRO(c)}

(a) Universidade de São Paulo - USP, School of Dentistry, Discipline of Endodontics, São Paulo, SP, Brazil.

(b) University of the Pacific, Arthur A. Dugoni School of Dentistry, Department of

Endodontics, San Francisco, CA, United States.

(c) Universidade Christus, Department of Dentistry, Post graduation Program in Dental Sciences, Fortaleza, CE, Brazil.

Declaration of Interests: Dr. Peters serves as a consultant for Dentsply Sirona. The remaing authors certify that they have no commercial or associative interest that represents a conflict of interest in connection with the manuscript.

\section{Corresponding Author:}

Giulio Gavini

E-mail: ggavini@usp.br

hitps://doi.org/10.1590/1807-3107bor-2018.vol32.0067

Submitted: May 05, 2018

Accepted for publication: May 29, 2018

Last revision: June 11, 2018

\begin{abstract}
The introduction of automated instrumentation in endodontics represented a major advance in progress for this specialty, with improvements in the quality and predictability of root canal preparation and a significant reduction in procedural errors. In recent years, endodontic instruments have undergone a series of changes brought about by modifications in design, surface treatments, and thermal treatments. In addition, new movements have also been incorporated to offer greater safety and efficiency, optimizing the properties of the NiTi alloy, especially through eccentric rotary motion. An understanding of the mechanical properties of these new NiTi instruments and their effect on the clinical performance of root canal preparation is essential if dental practitioners are to select the instruments that provide optimal clinical outcomes, especially in curved or flattened canals. The objective of this literature review is to present and discuss the characteristics of the NiTi alloys used in the major instrumentation systems available in the market, as well as the influence of the metallurgical and mechanical properties of NiTi instruments and the movements that drive them, to enable more accurate and predictable planning of root canal preparation.
\end{abstract}

Keywords: Endodontics; Root Canal Preparation; Dental Instruments.

\section{Introduction}

The introduction of nickel-titanium (NiTi) alloys and the subsequent automation of mechanical preparation were the first steps towards a new era in endodontics. These changes ushered in ever-greater progress in the specialty, with scientific and corporate research focused on developing instruments capable of meeting the needs for a more anatomically predictable root canal preparation, achievable in less time and with greater comfort for dentist and patient alike, as inflexible instruments have substantial difficulty following the curvature found in most root canal systems.

Over the last few years, many changes have been observed, including innovations in instrument design, surface and thermal treatments for NiTi alloys, and the incorporation and hybridization of new movement strategies to drive instrumentation systems. Knowing the morphological and mechanical characteristics of endodontic instruments, as well as their proper mode of use, provides greater security and versatility to the operator. 
Nickel-titanium alloy was originally developed for the U.S. space program at the Naval Ordnance Laboratory, in 1963, and was given the generic name "Nitinol". In dentistry, it was first used in 1971 by Andreasen and Hilleman, ${ }^{2}$ in the manufacture of orthodontic wires, due to its low modulus of elasticity, shape-memory effect, and superflexibility. Specifically in endodontics, Civjan et al. ${ }^{3}$ were the first to conceptualize the fabrication of endodontic instruments from NiTi alloy, in 1975. Later, in 1988, Walia, Brantley and Gerstein ${ }^{4}$ introduced the first handheld NiTi endodontic instruments, made by machining orthodontic wire. Thereafter, technological advances in the production of NiTi instruments allowed them to be manufactured by machining processes with significant changes in the configuration of the active part, variations in the helical angle and cut angle, and different increases in taper within the same instrument, no longer following the ISO standards published in 1958 for manual instruments. ${ }^{5}$

For many years, these instruments were fabricated exclusively through conventional machining, with variations mainly in the design of the cross-section, arrangement of the cutting surfaces along the active part, and presence or absence of radial surfaces; the major objective was to improve the cutting properties of the instrument and, particularly, reduce its risk of fracture. In this sense, the NiTi alloy treatments introduced since 1999 were the main factor responsible for changing the clinical behavior of these instruments.

Currently, more than 160 automated instrumentation systems are available, manufactured with different NiTi alloys, heat-treated or otherwise, with both superelastic (SE) and shape-memory (SME) properties, using rotational or reciprocating kinetics, centric or eccentric motion (Table). This paper aims to present a review of automated NiTi endodontic instruments, their mechanical properties, and the particular features of the main systems available today.

\section{Mechanical properties of nickel-titanium}

Most metallic materials exhibit an elastic behavior in which, within certain limits, the deformation caused is directly proportional to the force applied. This relationship is known as Hooke's Law. If the force applied exceeds a certain limit, it causes permanent deformation in the material (plastic deformation). According to Hooke's Law, most metal alloys can be elastically deformed by up to 0.1 or $0.2 \%$ beyond their elastic limit, or yield strength. Any deformation above this limit, known as the yield point, will be permanent. Nickel-titanium alloys, however, can be deformed up to $8 \%$ beyond their yield strength without showing any residual deformation. ${ }^{5,6}$ Superflexibility, or pseudoelasticity, can thus be defined as the ability of certain materials to recover their original shape after the load is removed even when they are deformed beyond their yield strength. ${ }^{7}$

According to Thompson ${ }^{5}$, the special properties of NiTi alloys are associated with a solid-state phase change: the martensitic transformation (MT). The MT is induced by the application of stress or by a temperature reduction, in which atoms move coordinately by a shear-type mechanism and are rearranged into a new, more stable crystalline structure, with no change in the chemical composition of the matrix, but with a macroscopic change in the shape of the material. This transformation occurs between austenite (the parent phase) and martensite.

When a material that undergoes MT is cooled below a certain temperature, the transformation is initiated by a shear mechanism, as shown in Figure 1. The martensitic regions in $A$ and $B$ have the same crystal structure, but the spatial orientations of the crystals are different. ${ }^{6}$

In MT caused by the cooling of the specimen, there is no change in shape, as the transformation mechanism is one of reversible, ordered selfaccommodation. ${ }^{8}$ If the material is heated while in the martensitic phase, the martensite becomes unstable, and reverse transformation (RT) occurs. The martensite thus returns to the austenite phase, and transformation follows the inverse path of MT.

Another important point is the shape-memory effect (SME), which is the ability of the alloy to completely recover its original shape when heated above the martensite-to-austenite transformation temperature, a temperature that varies according to the chemical composition of the alloy. Among the various metal alloys that exhibit superelasticity (SE) and the 
Nickel-titanium instruments in endodontics: a concise review of the state of the art

Table 1. Features of the main automated instrumentation systems in the current world panorama.

\begin{tabular}{|c|c|c|c|c|}
\hline $\begin{array}{l}\text { Instrument/ } \\
\text { Manufacturer (Year) }\end{array}$ & Application/Kinematics & Cross-section/Special Features & Diameter/Taper & Manufacturing/ Treatment \\
\hline Race/FKG (1999) & \multirow{3}{*}{ Shaping/Rotary centric } & \multirow{3}{*}{$\begin{array}{l}\text { Triangular with alternating cutting } \\
\text { edges along the instrument }\end{array}$} & & \multirow{12}{*}{$\begin{array}{l}\text { Micromilling, } \\
\text { Electropolishing }\end{array}$} \\
\hline IRace (2011) & & & $10-60$ & \\
\hline BioRace (2012) & & & $.02, .04, .06$ & \\
\hline \multirow{2}{*}{ Series ISO 10 (2010) } & \multirow{2}{*}{$\begin{array}{l}\text { Glide path/Rotary } \\
\text { centric }\end{array}$} & \multirow{2}{*}{ Quadrangular } & 10 & \\
\hline & & & $.02, .04, .06$ & \\
\hline \multirow{2}{*}{ Scout Race (2014) } & \multirow{2}{*}{$\begin{array}{l}\text { Glide path/Rotary } \\
\text { centric }\end{array}$} & \multirow{2}{*}{ Quadrangular } & $10,15,20$ & \\
\hline & & & .02 & \\
\hline \multirow{5}{*}{ BT Race (2014) } & \multirow{5}{*}{ Shaping/Rotary centric } & \multirow{5}{*}{$\begin{array}{l}\text { Triangular with alternating cutting } \\
\text { edges along the instrument }\end{array}$} & BT1 - 10.06 & \\
\hline & & & ВT2 - 35.00 & \\
\hline & & & ВT3 - 35.04 & \\
\hline & & & BT4 - 40.04 & \\
\hline & & & BT5 - 40.04 & \\
\hline K3/Sybron Endo (2001) & \multirow[t]{2}{*}{ Shaping/Rotary centric } & \multirow{2}{*}{$\begin{array}{l}\text { Triple-fluted, Positive rake } \\
\text { angle with asymmetric radial lands }\end{array}$} & $15-60$ & \multirow{2}{*}{$\begin{array}{c}\text { Micromilling } \\
\text { Micromilling, R-Phase }\end{array}$} \\
\hline K3XF (2011) & & & $.04, .06$ & \\
\hline Mtwo/VDW (2003) & Shaping/Rotary centric & $\begin{array}{c}\text { S-shaped with two active cutting } \\
\text { edges }\end{array}$ & $\begin{array}{c}10-60 \\
.04, .05, .06, .07\end{array}$ & Micromilling \\
\hline \multirow[t]{2}{*}{$\begin{array}{l}\text { ProTaper Universal/ } \\
\text { Dentsply-Sirona (2006) }\end{array}$} & \multirow{2}{*}{ Shaping/Rotary centric } & Convex triangular & \multirow{2}{*}{$\begin{array}{l}\text { Regressive taper } \\
\quad 17-50\end{array}$} & Micromilling \\
\hline & & $\begin{array}{l}\text { Variable and progressive tapers } \\
\text { along the instrument }\end{array}$ & & $\begin{array}{l}\text { Micromilling, post- } \\
\text { manufacture heat treatment }\end{array}$ \\
\hline \multirow[t]{2}{*}{ ProTaper Next (2013) } & \multirow[t]{2}{*}{ Shaping/Rotary centric } & \multirow[t]{2}{*}{ Rectangular eccentric } & $\begin{array}{l}\text { Variable taper } \\
\quad 17-50\end{array}$ & \multirow{2}{*}{$\begin{array}{l}\text { Micromilling, Pre- } \\
\text { manufacture heat } \\
\text { treatment: M-wire }\end{array}$} \\
\hline & & & $.04, .06, .07$ & \\
\hline \multirow{2}{*}{$\begin{array}{l}\text { Twisted File/Sybron } \\
\text { Endo (2008) }\end{array}$} & \multirow{2}{*}{ Shaping/Rotary centric } & \multirow{2}{*}{ Triangular } & $10-40$ & \\
\hline & & & $.04, .06, .08, .10, .12$ & \\
\hline \multirow{4}{*}{$\begin{array}{l}\text { Twisted File Adaptive } \\
\text { (2013) }\end{array}$} & & & $\mathrm{SM}-$ small & \\
\hline & & & $\begin{array}{c}25 / .04,25 / .06 \\
35 / .04\end{array}$ & $\begin{array}{l}\text { Twisted under heat, } \\
\text { R-Phase, Electropolished }\end{array}$ \\
\hline & Shaping/Adaptive & Triangular & $\mathrm{ML}$ - medium large & \\
\hline & & & $\begin{array}{c}25 / .08,30 / .06 \\
50 / .04\end{array}$ & \\
\hline EndoSequence/Brassler & Shanina/Retary centric & Triangular, with alternating contact & $15-60$ & Micromilling, \\
\hline (2009) & Shapıng/Rotary centric & points along the instrument & .04 e .06 & Electropolished \\
\hline $\begin{array}{l}\text { Profile Vortex/Dentsply } \\
\text { Sirona (2009) }\end{array}$ & & & $15-50$ & $\begin{array}{l}\text { Micromilling, Pre- } \\
\text { manufacture heat } \\
\text { treatment: M-wire }\end{array}$ \\
\hline Vortex Blue (2012) & Shaping/Rotary centric & Convex triangular & $.04, .06$ & $\begin{array}{l}\text { Micromilling, pre and } \\
\text { postmanufacture hea } \\
\text { treatment:Blue }\end{array}$ \\
\hline SAF/ReDent (2010) & Shaping/Nertical & Hollow & $1.5 \mathrm{~mm}$ & I gser cutting \\
\hline & vibration & & $2.0 \mathrm{~mm}$ & Laser cufting \\
\hline $\begin{array}{l}\text { Hyflex CM/Coltene } \\
(2011)\end{array}$ & & & $15-40$ & $\begin{array}{l}\text { Micromilling, Post- } \\
\text { manufacture heat } \\
\text { treatment: CM }\end{array}$ \\
\hline Hyflex EDM (2016) & Shaping/ Rotary centric & $\begin{array}{l}\text { Double fluted Hedström design } \\
\text { with positive rake ange }\end{array}$ & $.04, .06, .08$ & $\begin{array}{l}\text { Electrodischarge } \\
\text { Machining, post- } \\
\text { manufacture heat- } \\
\text { treatment: CM-EDM }\end{array}$ \\
\hline
\end{tabular}

Continue 


\begin{tabular}{|c|c|c|c|c|}
\hline Reciproc/VDW (2011) & Shaping/Reciprocating & $\begin{array}{l}\text { "S-shaped" } \\
\text { Single File technique }\end{array}$ & $\begin{array}{l}\text { Variable taper } \\
\text { R25 }(25 / 0.08) \\
\text { R40 }(40 / 0.06) \\
\text { R50 }(50 / 0.05)\end{array}$ & $\begin{array}{c}\text { Micromilling, } \\
\text { pre-manufacture } \\
\text { heat-treatment: } M \text {-wire } \\
\text { Micromilling, pre and } \\
\text { postmanufacture } \\
\text { hea-treatment: Blue }\end{array}$ \\
\hline R-Pilot (2017) & $\begin{array}{l}\text { Glide oath/ } \\
\text { Reciprocating }\end{array}$ & S-shaped & $\begin{array}{l}\text { Variable taper } \\
12.5 / 0.04\end{array}$ & $\begin{array}{l}\text { Micromilling, pre and } \\
\text { postmanufacture hea } \\
\text { treatment: Blue }\end{array}$ \\
\hline $\begin{array}{l}\text { Pathfile/Dentsply-Sirona } \\
\text { (2011) }\end{array}$ & $\begin{array}{l}\text { Glide-path/Rotary } \\
\text { centric }\end{array}$ & Quadrangular & $\begin{array}{c}13,16,19 \\
.02\end{array}$ & Micromilling \\
\hline $\begin{array}{l}\text { Typhoon/Clinician's } \\
\text { Choice (2011) }\end{array}$ & Shaping/Rotary centric & Convex triangular & $\begin{array}{l}20-35 \\
.04, .06\end{array}$ & $\begin{array}{l}\text { Micromilling, pre and } \\
\text { postmanufacture hea } \\
\text { treatment: CM }\end{array}$ \\
\hline $\begin{array}{l}\text { Wave One/Dentsply- } \\
\text { Sirona (2011) }\end{array}$ & & $\begin{array}{l}\text { Modified convex triangular (apical) } \\
\text { Convex triangular (coronal) }\end{array}$ & $\begin{array}{c}\text { Variable taper } \\
\text { Small }(21 / 0.06) \\
\text { Primary }(25 / 0.08) \\
\text { Large }(40 / 0.08)\end{array}$ & $\begin{array}{c}\text { Micromilling, } \\
\text { pre-manufacture } \\
\text { heat-treatment: } M \text {-wire }\end{array}$ \\
\hline Wave One Gold (2015) & Shaping/Reciprocating & Paralleogram & $\begin{array}{c}\text { Variable taper } \\
\text { Small (20/.07) } \\
\text { Primary }(25 / .07) \\
\text { Medium }(35 / .06) \\
\text { Large }(45 / .05)\end{array}$ & $\begin{array}{l}\text { Micromilling, post- } \\
\text { manufacture heat treatment }\end{array}$ \\
\hline $\begin{array}{l}\text { Wave One Glider } \\
\text { (2017) }\end{array}$ & $\begin{array}{l}\text { Glide path/ } \\
\text { Reciprocating }\end{array}$ & & $\begin{array}{c}\text { Variable taper } \\
15 / .02\end{array}$ & \\
\hline $\begin{array}{l}\text { Proglider/Dentsply- } \\
\text { Sirona (2014) }\end{array}$ & $\begin{array}{c}\text { Glide-path/Rotary } \\
\text { centric }\end{array}$ & Quadrangular & $\begin{array}{c}\text { Variable Taper } \\
\text { 16/.02 }\end{array}$ & $\begin{array}{l}\text { Micromilling, pre- } \\
\text { manufacture heat- } \\
\text { treatment: M-wire }\end{array}$ \\
\hline $\begin{array}{l}\text { ProDesign Logic/Easy } \\
(2014)\end{array}$ & Shaping/Rotary centric & Triangular & $\begin{array}{c}25 / 50 \\
.03, .05 .06\end{array}$ & \\
\hline $\begin{array}{l}\text { ProDesign Logic Glide- } \\
\text { Path/Easy (2014) } \\
\text { ProDesign R/Easy } \\
(2014)\end{array}$ & $\begin{array}{l}\text { Glide-path/ Rotary } \\
\text { centric }\end{array}$ & Double Helix & $\begin{array}{c}25-50 \\
.01 \\
\text { Single File } \\
25 / .08\end{array}$ & $\begin{array}{l}\text { Micromilling, } \\
\text { post-manufacture heat } \\
\text { treatment: CM }\end{array}$ \\
\hline $\begin{array}{l}\text { TRUShape/Dentsply- } \\
\text { Sirona (2015) }\end{array}$ & $\begin{array}{l}\text { Shaping/Rotary } \\
\text { eccentric }\end{array}$ & $\begin{array}{c}\text { Triangular } \\
\text { S-curve in the instrument's } \\
\text { longitudinal axis }\end{array}$ & $\begin{array}{l}\text { Variable regressive } .06 v \text {. } \\
\qquad 20-40\end{array}$ & $\begin{array}{c}\text { Micomilling, Shape-setting, } \\
\text { Heat-treatment }\end{array}$ \\
\hline $\begin{array}{l}\text { XP-endo Shaper/FKG } \\
\text { Dentaire (2015) }\end{array}$ & $\begin{array}{l}\text { Shaping/Rotary } \\
\text { eccentric }\end{array}$ & Triangular Booster Tip & $\begin{array}{c}\text { Single file } \\
15-30 \\
.01-\text { minimum .04 }\end{array}$ & $\begin{array}{c}\text { Micomilling, Shape-setting, } \\
\text { Heat-treatment }\end{array}$ \\
\hline $\begin{array}{l}\text { Genius/Ultradent } \\
(2016)\end{array}$ & $\begin{array}{l}\text { Shaping/Rotary and } \\
\text { reciprocating centric }\end{array}$ & S-shaped & $\begin{array}{c}25-50 \\
.04\end{array}$ & $\begin{array}{l}\text { Micromilling, heat } \\
\text { treatment }\end{array}$ \\
\hline $\begin{array}{l}\text { Sequence Rotary File/ } \\
\text { MK life (2017) }\end{array}$ & Shaping/Rotary Centric & & $\begin{array}{l}15-35 \\
.04, .06\end{array}$ & \\
\hline X1 Blue/MK life (2017) & Shaping/Reciprocating & Triangular & $\begin{array}{c}\text { Single file } \\
20,25,40 \\
.06\end{array}$ & $\begin{array}{l}\text { Micromilling, post- } \\
\text { manufacture heat treatment }\end{array}$ \\
\hline $\begin{array}{l}\text { Typhoon/Clinician's } \\
\text { Choice (2011) }\end{array}$ & Shaping/Rotary tentric & Convex triangular & $\begin{array}{l}20-35 \\
.04, .06\end{array}$ & $\begin{array}{l}\text { Micromilling, } \\
\text { post-manufacture heat } \\
\text { treatment: CM }\end{array}$ \\
\hline
\end{tabular}

* CM: Controlled-memory 


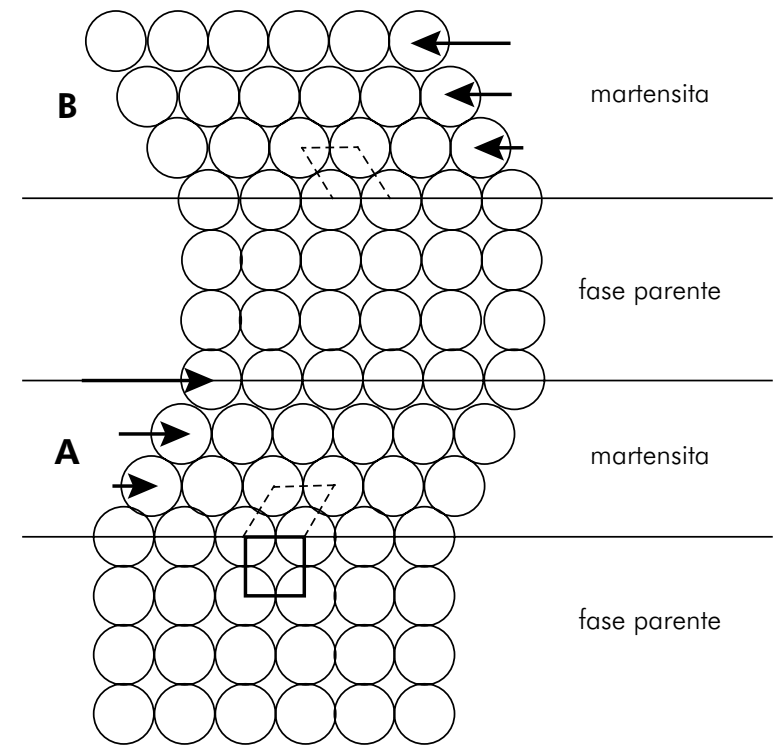

Figure 1. Simplified model of martensitic transformation according to Otsuka and Wayman. ${ }^{6}$

SME, nickel-titanium has the best biocompatibility and corrosion resistance, due to its surface coating of titanium oxide. ${ }^{6}$ The superelasticity of NiTi alloys is associated with substantial recoverable deformation (up to $15 \%$ ) when subjected to loading and unloading at an appropriate temperature. In SE, the driving force of the transformation is mechanical, whereas in the SME, both thermal and mechanical processes are implicated..$^{10}$

\section{Conventional (untreated) nickel- titanium instruments}

The first NiTi rotary instruments, still with the ISO-standard .02 taper, were introduced in 1992, designed by Dr. John McSpadden. Two years later Dr. Johnson introduced the ProFile .04 and Profile $.06 \mathrm{NiTi}$ rotary systems, breaking the longstanding paradigm of manufacturing endodontic instruments exclusively with the standard .02 taper. The ProFile system instruments had a U-shaped cross-section, with a radial land similar to that of the stainless steel instruments of the Canal Master U System, designed by Dr. Steve Senia in 1988. The LightSpeed NiTi rotary system, created by Dr. Steve Senia and Dr. William Wildey, has a similar cross-section, as does the Greater Taper (GT) system developed by Dr. Steve Buchanan. What distinguishes the LightSpeed system from others is the presence of a long, flexible shaft and a single, short cutting length $(0.25-2 \mathrm{~mm})$ with a non-cutting guide tip, which allows shaping of the apical region alone without the need for excessive enlargement of the coronal and middle thirds of the canal. In the late 1990s, Dr. John McSpadden introduced the Quantec NiTi rotary system, consisting of 10 files of different sizes, diameters, and tapers. The evolution of Quantec was represented by the $\mathrm{K} 3$ system, which incorporated instruments with significant differences in relation to the other existing systems at the time. The unique cross-sectional design of this system, with three cutting flutes, a positive rake angle, and asymmetrical radial lands, provides excellent cutting capacity. ${ }^{11}$

A new concept in file design was introduced in 2001 with the ProTaper system (Dentsply Sirona, York, PA, USA), which incorporates varying, progressive tapers along the cutting flutes of the same instrument. This feature, combined with a convex triangular cross-section, allows the instruments to work in a specific area of the canal during crown-down preparation, reducing file contact with the dentin walls and, consequently, reducing stress on the instrument. ${ }^{12}$ In 2006, due to the need for improvement of its characteristics, the cross-section of some of the instruments was modified and the system was expanded, with the addition of additional apical preparation files, giving rise to a new generation of the system: the ProTaper Universal. These modifications sought to increase flexibility and, consequently, reduce instrument fractures. ${ }^{13,14}$

Proposing an instrumentation strategy different from that of most rotary systems, the $\mathrm{M}_{\mathrm{two}}$ system (VDW, Munich, Germany) has an S-shaped crosssectional design that allows preparation of the entire working length from the very start, from apex to crown, with each instrument creating a glide path for the next, without unnecessary removal of tooth substance. ${ }^{15}$ The cutting edges become closer to each other at the tip of the instrument, allowing a more delicate cutting action in the apical region and more efficient cutting in the cervical third, as well as reducing debris buildup ${ }^{16,17}$ and decreasing the 
screw-in effect. ${ }^{18}$ Schäfer et al. ${ }^{19}$ compared the efficacy of shaping simulated curved canals using $\mathrm{M}_{\mathrm{two}}{ }^{\circledR}$, $\mathrm{K} 3 \AA$, and Race ${ }^{\circledR}$ files, and concluded that the $\mathrm{M}_{\mathrm{two}}$ instruments prepared curved canals more quickly, respecting their original curvature, but the number of fractured instruments was greater than with the Race and K3 systems. Recently, Shivashankar et al. ${ }^{20}$ reported similar findings regarding dentin volume removed and canal transportation in the preparation of mesial molar canals with the $\mathrm{M}_{\mathrm{two}}$ ProTaper, and Protaper NEXT systems.

\section{NiTi alloy treatments}

Despite the advantages provided by the superelasticity of the NiTi alloy, instrument fracture is still a clinical concern. Possible strategies to increase efficiency and safety of NiTi rotary files include improvements in the manufacturing process or the use of new alloys that provide superior mechanical properties. ${ }^{21,22}$ The mechanical properties and behavior of the NiTi alloy vary according to its chemical composition and thermal/mechanical treatment during manufacturing. ${ }^{6,23,24} \mathrm{~A}$ timeline of these treatments is presented in Figure 2.

\section{Electropolishing: electrochemical surface treatment}

Electropolishing (electrochemical surface treatment) was introduced by FKG (La Chaux-de-Fonds, Switzerland) in 1999. After the machining process, instruments receive this surface treatment, which increases cutting efficiency while reducing defects resulting from the manufacturing process, thereby increasing fatigue resistance..$^{25,26}$ The Race system (FKG, La Chaux-de-Fonds, Switzerland), manufactured using this technology, remains available worldwide with several variations and clinical sequences. ${ }^{27,28}$ The Race instruments have a triangular cross-section and cutting edges arranged alternately with respect to the axis of the instrument, in the longitudinal and oblique directions. According to the manufacturer, this design reduces the feed speed and the screw-in effect within the root canal. ${ }^{27}$ The main objective of this system is to achieve a more biological canal preparation, with larger apical diameters, ${ }^{29}$ which helps the chemical irrigant penetrate further, thus contributing to greater microbial reduction, with minimal apical transportation. ${ }^{30,31}$ Busquim et al. ${ }^{32}$ compared preparation with the BioRace sequence versus the Reciproc system, and concluded that, while the latter produced greater volumetric gain in the canal, the BioRace system left a smaller area of untouched dentin walls in the middle and cervical thirds.

More recently, a new generation of the Race system - the BT-RaCe instruments - was introduced. These instruments have a special non-cutting "booster tip" (BT) up to $0.17 \mathrm{~mm}$ in length with six cutting edges and a reduced diameter, which, according to the manufacturer, facilitates progression of the instrument to the apical region of the root canal while maintaining its original curvature. They are available in a simplified sequence with three instruments: BT-1 (10/.06), BT-2 (35/.00), and BT-3 (35/.04), as well as two supplemental instruments for when greater enlargement of apical diameter is required. Bürklein et $a l .{ }^{33}$ recommend that the second instrument of the series (BT-2) should be used in a delicate, smooth pecking motion, because it is less resistant to buckling than an instrument of the same diameter and greater taper, due to its cylindrical design, which also makes progression of this instrument more

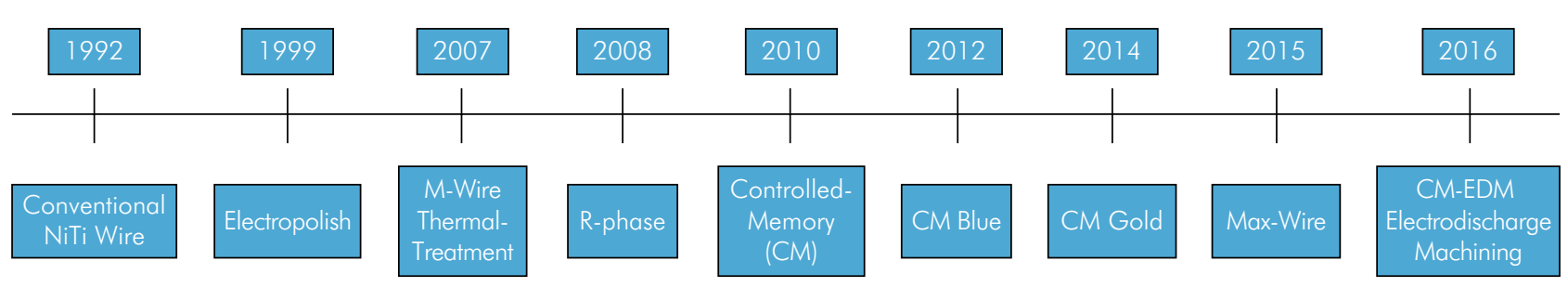

Figure 2. Evolution of NiTi Alloy Treatments 


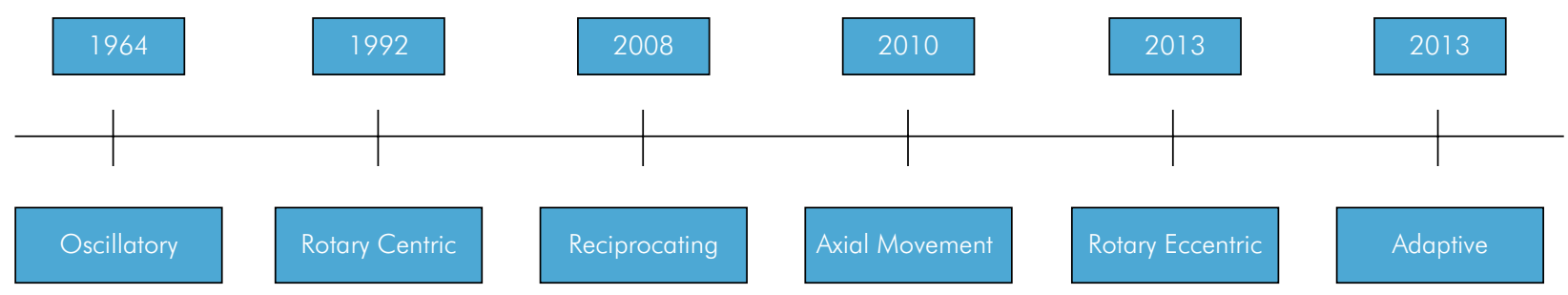

Figure 3. Timeline of movements used in mechanical root canal preparation

time-consuming. These authors ${ }^{33}$ also reported that root canal preparation with the BT-Race system was more time-consuming than with the ProTaper NEXT system. Brasil et al. ${ }^{34}$ found similar results in the quality of the preparation of mesial mandibular molar canals with the BT-Race and ProTaper NEXT systems, which produced minimal apical transportation, despite their different manufacturing characteristics. The authors suggest that the BT tip and triangular cross-section of the former can compensate for the lower flexibility of its conventional austenitic alloy.

Similar to the Race system, the EndoSequence instruments (Brasseler, Savannah, GA, USA) also undergo electrochemical treatment after machining, which consists of immersion in an ionic solution through which an electric current passes to remove any irregularities generated during the manufacturing process. ${ }^{35}$ However, some authors state that other factors, such as instrument design, play a more critical role in determining an instrument's cyclic fatigue resistance than its surface finish does. ${ }^{36}$ According to Ray et al., ${ }^{37}$ the EndoSequence system is associated with a higher rate of fracture when compared to $\mathrm{K} 3$ instruments (which do not undergo any surface treatment) with the same tip size and taper, regardless of speed (300 or 600rpm). Testarelli et al. ${ }^{38}$ and Viana et al. ${ }^{39}$ attributed the greater flexibility of the EndoSequence as system compared to the Hero, FlexMaster, and Profile systems to its design elements (lower metal mass and presence of alternate contact points throughout the instrument). Freire et al. ${ }^{40}$ showed that the EndoSequence system was associated with minimal transportation when preparing curved canals, similar to Twisted Files, whereas Williamson et al. ${ }^{41}$ found the EndoSequence system to be as effective as the ProTaper and ProFile GT Systems, removing the same amount of smear layer and dentin debris.
The One Shape system from MicroMega (Besançon Cedex, France), launched in 2011, introduced an innovative concept of single-file canal preparation with centric rotary motion. Its asymmetrical edge design and electrolytic surface treatment aim to make the instrument more resistant to fractures. There are three cutting angles extending from the tip of the instrument to $2 \mathrm{~mm}$ along its length; the middle of the instrument transitions to two cutting angles, which extend up to the region closest to the handle. In 2014, some changes were made to the system, mainly regarding its cross-section, which became variable, acquiring a more rectangular or "S" shape near the top of the shaft and becoming more triangular at the tip. The taper is .06 in the first $5 \mathrm{~mm}$, followed by virtually no taper along the shaft and towards the handle of the instrument.

Nabeshima et al. ${ }^{42}$ compared bacterial reduction in distal canals of $E$. faecalis-infected upper molars instrumented with the One Shape or WaveOne systems. Their results show that both systems reduced bacterial burden, with no significant differences between them. Studies evaluating the ability of the One Shape system to shape and maintain canal curvature reported inferior results when compared to the Twisted File and WaveOne systems, ${ }^{43}$ as well as lower cyclic fatigue resistance when compared to the Reciproc system. ${ }^{4}$

Heat treatment consists of heating a material to a given temperature and cooling it under controlled conditions, after a set period of time, in order to obtain specific properties (SE and SME). These two properties are influenced by temperature, heating time, and cooling rate.

The martensite phase is readily elastically deformable and can be induced by temperature 
(cooling) or stress. The phase transition temperatures depend on the chemical composition of the alloy, the heat treatment process, and the cold working parameters. ${ }^{45}$ Analysis of samples of NiTi endodontic instruments have revealed that the alloy is completely austenitic, and thus superelastic, at room temperature. ${ }^{46}$ The differences between NiTi alloys are their nickel content and their temperature ranges of MT. The composition of the alloy can be varied to obtain wires with SME or SE. ${ }^{5}$ Transformation temperatures are highly dependent on the nickel concentration of the alloy. In the Ti-rich region, transformation temperatures are almost independent of alloy composition, and run in the region of $60^{\circ} \mathrm{C}$. On the Ni-rich side, increasing nickel content results in a drastic decrease in transformation temperature. ${ }^{8}$

Most interest has focused on Ni-rich alloys, due to the ability to control transformation temperature by varying the $\mathrm{Ni}$ content. On the Ni-rich side, $\mathrm{Ti}_{3} \mathrm{Ni}_{4}$ precipitates can be formed from $\mathrm{TiNi}_{3}$ decomposition; these finely dispersed precipitates cause the alloy matrix to harden and improve the recovery capacity of the SME, as well as the superelastic property. ${ }^{47}$ These precipitates $\left(\mathrm{TiNi}_{3}\right)$ can affect the characteristics of martensitic transformation and act as nucleation centers for formation of the $\mathrm{R}$ phase. The fine precipitates are capable of changing the MT process from austenite-martensite to austenite-R-martensite. For NiTi alloys in which SME is desired, the Ni content limits range from $48 \%$ to $52 \% \mathrm{Ni}$ by weight. As noted above, transformation temperatures are strongly dependent on the $\mathrm{Ni} / \mathrm{Ti}$ ratio, and are sensitive to the addition of alloying elements.

Heat treatments may entail four different reactions in the solid state: a) change in chemical composition (precipitation); b) reorganization of defects (recovery); c) reduction of defects (recrystallization); and c) structural phase transformation. SME alloys are materials that can use these "combined reactions". The heat treatments performed in NiTi alloys with the aim of improving their properties are: aging, annealing, and recrystallization. Aging alloys yields higher mechanical strength. The aging process consists of uniform heating of the alloy to about $500^{\circ} \mathrm{C}$ followed by rapid cooling (quenching), usually in water, to temporarily prevent precipitation of the alloying elements. The purpose of annealing is to eliminate the hardness of a tempered part or to normalize materials with internal stresses. The material is heated to $300-500^{\circ} \mathrm{C}$ until the desired changes have taken place over the entire mass of the part, which is then cooled slowly. Recrystallization is the replacement of a cold-deformed structure by a new set of deformation-free grains, as evidenced by a reduction in hardness and an increase in ductility. To eliminate the hardening effect caused by cold forming, annealing is performed to achieve recrystallization. During this process, no phase transformation should occur, and cooling cannot be induced.

In 2007, Tulsa Dental developed a new NiTi alloy known as M-Wire, composed of Nitinol 508 (55.8\% Ni by weight, Ti completing the balance), which undergoes unique thermal treatments at various temperatures, done before the instruments are machined. This material contains both the martensite and $\mathrm{R}$ phases, while maintaining pseudoelasticity. Compared to instruments fabricated from conventional NiTi alloys, instruments made from M-Wire alloy have higher cyclic fatigue resistance and improved mechanical properties. ${ }^{13,21,48,49}$ One example is the ProTaper NEXT system, introduced in 2013 as the successor to the ProTaper Universal; in addition to being manufactured from M-Wire alloy, it includes a change in instrument cross-section, which is in this design quadrilinear with an offset. This design means that only two cutting edges touch the canal wall during apical advancement of the instrument, giving it an eccentric rotary motion. In addition, the files have superior flexibility and fatigue resistance ${ }^{50}$ and are associated with shorter instrumentation time when compared to the ProTaper Universal system..$^{50}$

Another system made from M-Wire alloy is the ProFile Vortex system (Dentsply Sirona, York, PA, USA), a modification of the traditional ProFile series that has higher fatigue resistance than its predecessor. ${ }^{51,52}$ The manufacturer suggests that the Profile Vortex system can be operated at up to 500rpm and that this increased working speed, along with its geometry, improves the cutting efficiency of the instruments. ${ }^{53,54}$ According to Rhodes et al., 55 ProFile Vortex instruments were associated with few differences in the preparation of curved root canals. 
In 2008, Sybron Endo introduced a series of mechanical NiTi instruments subjected to a special heat treatment after completion of the machining process, which creates an additional phase change in the crystal structure of the alloy to improve flexibility and strength, besides accommodating some of the internal stress caused by machining. ${ }^{56}$ As noted above, this phase of the NiTi alloy (the R phase) is an intermediate phase between martensite and austenite, and occurs during martensitic transformation when cooling to the $\mathrm{R}$ phase, as well as from the $\mathrm{R}$ phase to martensite. ${ }^{6}$

The K3XF and Twisted File (TF) systems, both manufactured by Sybron Endo, receive this treatment. K3XF, an evolution of the K3 system, has demonstrated better mechanical properties compared to $\mathrm{K} 3$ instruments manufactured by the traditional process. ${ }^{57,58,59}$ It has a variable pitch that becomes deeper as the diameter of the file increases from the tip to the end of the active part, which reduces instrument mass in areas with larger diameter, thus reducing stiffness. The Twisted File system, besides its R-phase treatment, was the first NiTi file manufactured by plastic deformation, in what constituted a major advance in endodontic instrument technology. ${ }^{60}$ Through this fabrication method, which involves twisting a metal rod and heat-treating it to recrystallization, the TF system provides greater elasticity and superior cyclic fatigue resistance compared to instruments made from SE nickel titanium. ${ }^{61} \mathrm{TF}$ instruments also receive a special electrochemical surface conditioning treatment with an oxidation bath, increasing the hardness of the file without changing its flexibility. This unique twisting fabrication process ensures greater integrity of the crystal lattice structure of the metal, as the core of the structure is never sectioned, nor are cross-sectional striations (which facilitate fracture propagation) machined into the instrument. ${ }^{62}$

In 2010, instruments manufactured with CM-Wire (controlled memory) thermal treatment technology were introduced by DS Dental (Johnson City, TN, USA). After machining of Nitinol SE508, a heating and cooling process gives the alloy control over the shape-memory effect, allowing the instruments to be pre-bent, which confers greater fatigue resistance ${ }^{63,64}$ and flexibility, ${ }^{38,65}$ contributing to a more centered canal preparation and lower rates of transportation. ${ }^{66,67}$ These instruments also contain less nickel (52\%) than conventional SE alloys (54\% to $57 \%$ ), which improves the mechanical properties of the alloy. Recent studies demonstrate that the final austenite-phase manufacturing temperature of Hyflex CM instruments is generally around $47^{\circ} \mathrm{C}^{68,69}$ suggesting that at room temperature the instrument may be a composite of R-phase martensite and austenite, ${ }^{68,70}$ unlike conventional NiTi instruments, which are purely austenitic. ${ }^{71}$ After sterilization of the instrument, it returns to its original phase and can be reused, until inverted deformation finally occurs, signaling that it should be discarded. Another evidence in favor of CM-treated instruments is that, despite having lower tensile strength (1094 MPa versus $1415 \mathrm{MPa}$ in conventional NiTi), they have a higher capacity to withstand deformation before fracture ( $58.4 \%$ to $84.7 \%)$ than conventional ones (16.7\% to $27.5 \%)$, indicating the superior flexibility of these instruments. ${ }^{68}$ Other studies confirm that CM instruments have $>300 \%$ greater resistance to cyclic fatigue when compared to SE instruments. ${ }^{22,38,68}$

In 2011, Coltene/Whaledent (Cuyahoga Falls, OH) introduced the Hyflex line with instruments made from CM-Wire (Controlled Memory Wire, Johnson City, TN, USA). The system consists of instruments developed to work specific regions of the root canal, starting with removal of cervical interferences with an orifice shaper, followed by preparation of the middle and apical thirds, and ending with more tapered instruments for final shaping. The \#25.08 Orifice Shaper has a triangular cross-section, which increases its cutting potential. The next instruments have a .04 taper and a quadrangular cross-section, which improves resistance to the narrower regions of the root canal. Final shaping is performed using instruments with a triangular cross-section, .04 and .06 taper, and a larger tip diameter. The Hyflex CM instruments, compared to other NiTi SE systems, exhibit greater resistance to cyclic fatigue. ${ }^{72,73,74}$. In addition, approximately $90 \%$ of Hyflex CM instruments undergo plastic deformation during manufacturing, but return to their initial condition once autoclaved. ${ }^{72,75,76}$ 
More recently, in 2016, the same manufacturer introduced the Hyflex EDM system (Coltene/ Whaledent, Cuyahoga Falls, $\mathrm{OH}$ ), also made from NiTi CM 495 alloy, but manufactured using sparkerosion technology, widely used in engineering. ${ }^{77}$ This electrical discharge machining, or EDM, is a noncontact thermal erosion process employed in the manufacture of electrically conductive materials which uses controlled electric discharges in the presence of a dielectric fluid. This process "melts" the surface of the metal (in this case, a nickel titanium alloy), partially evaporating small portions of the metal and leaving behind an eroded surface. ${ }^{78}$ The instrument is then heat-treated at temperatures between 300 and $600^{\circ} \mathrm{C}$ for 10 minutes to 5 hours, before or after ultrasonic cleaning and an acid bath. ${ }^{79}$ The EDM manufacturing method seems to optimize the fracture strength of the instrument, by increasing cyclic fatigue resistance by more than $700 \%$ at room or body temperature. ${ }^{77,80,81,82}$ Uslu et al ${ }^{83}$ recently evaluated the surface structure of Hyflex CM and Hyflex EDM instruments before and after use on teeth with severely curved canals. EDM instruments exhibited fewer altered surfaces after preparation, demonstrating better structural preservation when compared to Hyflex CM. Another important feature of the Hyflex EDM system is the design of the instruments, which have different crosssections along the cutting surface. Near the handle, the cross-section is triangular to provide better cutting efficiency; in the middle portion, it is trapezoidal, providing greater resistance and greater debris clearance; and the tip is quadrangular, facilitating penetration of the instrument and reducing the risk of fracture.

Also made from CM-Wire, the ProDesign R and ProDesign Logic systems (Easy Dental Equipments, Belo Horizonte, MG, Brazil) have an S-shaped crosssection, inactive tip, and variable helical angles with two cutting edges. According to the manufacturer, the systems differ only in the cutting direction of the edges; ProDesign Logic is used in centric rotary motion, which reduces the screw-in effect, while ProDesign $R$ is designed for reciprocating motion, with angulations similar to those of the WaveOne system.

The ProDesign Logic system aims to unite the concept of a single-file system, and comprises shaping files $(25 / 0.06,30 / 0.05,35 / 0.05,40 / 0.05)$ and glide path files (25/0.01, 30/0.01,35/0.01, 40/0.01). Menezes et al. ${ }^{84}$ evaluated the Easy systems and found that ProDesign R and ProDesign Logic had greater cyclic fatigue resistance than WaveOne Gold. The authors attribute this result to the differences in cross-section of the instruments and to the use of glide path files.

Typhoon Infinite Flex instruments (Clinician's Choice Dental Products, New Milford, CT, USA), also manufactured with NiTi CM-Wire, were up to $150 \%$ more fatigue-resistant than instruments manufactured with NiTi M-Wire and 390\% stronger than conventional alloy instruments. ${ }^{52,85,86}$ Acosta et al. ${ }^{87}$ evaluated cyclical deformation in torsional resistance between conventional NiTi (Race and ProTaper Universal) and CM-Wire (Typhoon and Hyflex) instruments, with the latter showing greater resistance.

In 2012, Dentsply Sirona introduced a new heat treatment process for NiTi CM alloys, whereby instruments are repeatedly heat-treated and then cooled, which results in a surface color corresponding to the thickness of the layer of titanium oxide. ${ }^{88}$ The Vortex Blue (Dentsply Sirona), Sequence Rotary File and X1 Blue File (MK Life, Porto Alegre, RS, Brazil), Reciproc Blue (VDW), ProTaper Gold (Dentsply Sirona), and WaveOne Gold systems are manufactured using this technology. In the NiTi Blue Wire alloy, the thickness of the titanium oxide layer is $60-80$ $\mathrm{nm}$, whereas in the NiTi Gold alloy, this thickness is $100-140 \mathrm{~nm}^{89}$

The rigid titanium oxide layer on Vortex Blue instruments compensates for the loss of hardness compared to ProFile Vortex instruments, increasing cutting efficiency and wear resistance ${ }^{90}$ (Plotino et al. 2014). The Vortex Blue system also has better fatigue resistance and flexibility compared to the ProFile Vortex system ${ }^{26}$ and to the ProTaper Next and ProTaper Universal systems. ${ }^{63.91}$

The Sequence Rotary File system (MK Life, Porto Alegre, RS, Brazil) also comprises instruments manufactured with this technology, which gives them a bluish tint. It consists of four instruments with 0.4 and $0.6 \mathrm{~mm}$ taper and diameters \#15, \#20, \#25 and \#35. All instruments have an inactive tip and triangular cross-section. 
ProTaper Gold is similar to the ProTaper Universal system with regard to the morphology of the files, including sizes, taper, and cross-section. It is distinguished by the Gold thermal treatment, which increases its flexibility and resistance to cyclic fatigue, helping ensure a more centered preparation of curved canals..$^{92}$ In addition, the connecting handle is shorter than that of ProTaper Universal files (11mm), which facilitates clinical access to the root canal system.

Recently, a special NiTi alloy known as MaxWire (Martensite-Austenite Electropolishing-Flex, FKG) was developed for the manufacture of instruments in the XP-endo family (FKG): XP-endo Finisher (XP-F), XP-endo Finisher Retreatment (XP-R), and $\mathrm{XP}$-endo Shaper (XP-S). As a result of the alloy treatment, at temperatures equal to or greater than $35^{\circ} \mathrm{C}$, it shifts from the martensitic to the austenitic phase, giving the instrument a semi-circular shape that allows it to project against the walls of the root canal when rotating, performing eccentric rotary motion. Thus, XP-endo instruments are able to adapt to the morphology of the root canal system, expanding or contracting as they advance along the working length. The XP-endo Finisher has an ISO 25 diameter and zero taper (25/.00). Its main purpose is to provide supplementary cleaning of the canal at the end of chemical and mechanical preparation by touching hard-to-reach areas of the root canal walls, preserving dentin and the internal anatomy of the canal. It has been reported that the mechanical action of XP-F, when combined with agitation of the irrigant, promoted greater bacterial reduction ${ }^{93}$ and biofilm removal from the main canal and dentin tubules. ${ }^{94}$ Leoni et al. ${ }^{95}$ also found greater percent reductions in dentin debris with the XP-F instrument as compared with passive ultrasonic irrigation (PUI), while Keskin et al. ${ }^{96}$ showed that XP-F and PUI promoted better removal of calcium hydroxide in canals with simulated internal resorption cavities. These positive findings are believed to be attributable to the design of the instrument, which, together with its kinetic action, ensures wide-ranging movements with high-speed rotation, allowing space for the flow of irrigant and clearance of dentin debris, microorganisms, and intracanal medicaments from the root canal system.
The XP-endo Shaper, as its name implies, is an instrument designed for root canal shaping. It performs an eccentric rotary motion by taking on a semicircular shape when it expands at temperatures equal to or greater than $35^{\circ} \mathrm{C}$. In the early stages of preparation, still at room temperature, it is in the martensitic phase; when introduced into the canal, it changes its shape due to the molecular memory of the austenitic phase. It has a Booster tip that gives it a unique geometry, with six sharp edges at the tip and an ISO 15 initial diameter, which increases gradually to a diameter of ISO 30 and 0.01 taper. According to the manufacturer, after expanding, the XP-endo Shaper reaches a final canal preparation corresponding to \#30/.04; however, few studies have been performed with this system. Azim et al. ${ }^{97}$ demonstrated that XP-S had the ability to expand beyond the size of its core to conform to the anatomy of the root canal space by preparing and touching more walls in oval canals than the Vortex Blue system. The XP-S group also achieved significantly faster completion of mechanical preparation, by almost 1 minute; however, the final taper of the preparation varied according to the anatomy of the treated tooth. Lacerda et al. ${ }^{98}$ did not find significant differences between the XP-endo Shaper system and the TRUShape or Self Adjusting File (SAF; ReDentNOVA, Ra'anana, Israel) systems for preparation of oval canals. Regarding cyclic fatigue resistance, Elnaghy and Elsaka ${ }^{99}$ compared the XP-endo Shaper with the TRUShape, Vortex Blue, iRace, and HyFlex CM systems. They concluded that the improvements provided by the MaxWire alloy and lower taper of the XP-S instrument improved its resistance to cyclic fatigue. Silva et al. ${ }^{100}$ also found a greater number of cycles completed until fracture for XP-S as compared to TRUShape instruments. On the other hand, Elnaghy and Elsaka ${ }^{101}$ conducted an evaluation of torsional strength and did not find an increase in resistance to torsional stress in the XP-endo Shaper when compared to the TRUShape, ProFile Vortex and FlexMaster systems.

Two new instruments, ONE Endo and EXO Endo, were developed from a single concept: to incorporate two or more different tapers into the same instrument, in what the manufacturer calls a "Delta-type design". The instruments have a so-called "cut flip tip", which, according to the manufacturer, is able to enlarge 
narrower canals more effectively, with less stress to the instrument, less extrusion of debris, less blockage, and less need for a glide path. This design also preserves the dental structure during preparation of the cervical portion of the canal, while simultaneously providing enlargement of the apical region. The ONE Endo instrument must be used for initial enlargement, followed by the EXO Endo for final shaping.

Recently, MicroMega released the 2Shape system, which consists of two instruments (\#25/.04 and \#25/.06), plus two options for wider canals (\#35/.06 and \#40/.04). They share the same features of single-file One Shape instruments, but with a new asymmetric edge design that improves debris removal and increases cutting power. In addition, a new heat treatment system known as T-Wire Technology was introduced, which, according to the manufacturer, optimizes cyclic fatigue resistance by $40 \%{ }^{74}$

Özyürek et al ${ }^{102}$ compared the HyFlex EDM, WaveOne Gold, Reciproc Blue, and 2Shape systems by analyzing the time and number of cycles required to fracture the instruments. Hyflex EDM had higher cyclic fracture strength than the other systems in curved canals. In sharply curved canals, the Reciproc Blue system exhibited better results.

\section{Movements used in mechanical root canal preparation}

The introduction of NiTi instruments has made the process of mechanical root canal preparation more predictable in the clinical setting, with a significant reduction in working time and less stress on the practitioner. Centric rotary motion, introduced in the late 1980s, is still employed by the majority of mechanical preparation systems on the market today. It is performed by electric motors and reduction contra-angle handpieces driving NiTi files in full rotation $\left(360^{\circ}\right)$ within the root canal. However, new mechanized techniques have been proposed in an attempt to minimize the risk of fracture of endodontic instruments. Reciprocating motion also uses electric motors and contra-angle handpieces that drive NiTi files, but in this case the angles of rotation are asymmetrical, in the counterclockwise and clockwise directions

\section{Reciprocating movement}

Yared ${ }^{103}$ carried out a study where all canal preparation was performed with a single F2 ProTaper file, using reciprocating motion, with different angles of rotation in the counterclockwise and clockwise directions, facilitating advancement of the instrument with little apical pressure. This landmark study represented an evolution in endodontic instrument kinematics, as the use of sequential files would no longer be necessary to achieve tapered shaping of the root canal system.

Thus, new reciprocating instruments were developed for single-file preparation, such as the Reciproc (VDW) and WaveOne (Dentsply Sirona) systems, both made from M-Wire alloy. These two instrument systems work in centric reciprocating motion, rotating initially counterclockwise (Reciproc $150^{\circ}$, Wave One $170^{\circ}$ ) to cut away dentin and clockwise (Reciproc $30^{\circ}$, WaveOne $50^{\circ}$ ) to clear it, in order to avoid the screw-in effect that occurs with some continuous rotary systems. The angles of rotation were calculated to be below the degree necessary for fracture of the instrument if it binds to dentin, thus making for a safer technique. Most systems cut counterclockwise (Reciproc - VDW; Reciproc Blue VDW; Wave One - Dentsply Sirona; Wave One Gold - Dentsply Sirona; Pro Design R - Easy; Unicone MK Life; X1 Blue File - MK Life), although there are systems with clockwise cutting action (Genius Ultradent, Pro Design S - Easy). The angles of rotation range from approximately $60^{\circ}$ to $90^{\circ}$ clockwise and $120^{\circ}$ to $270^{\circ}$ counterclockwise.

Studies have shown that reciprocating motion induces lower tensile and compressive stress in the flexed region of the instrument, thus providing greater fatigue resistance when compared to continuous rotary motion..$^{2,104}$ Plotino et al. ${ }^{90}$ conducted a clinical evaluation of fracture and deformation rates using a total of 1,696 Reciproc instruments, and found very low incidence of both (fracture, $0.47 \%$; deformation, $0.35 \%$ ). Despite the risk of instrument separation, the reuse of reciprocating systems for more than one case is relatively common in clinical practice. In an in vivo study, Bueno et al. ${ }^{105}$ used Reciproc R25 and WaveOne Primary instruments in up to three posterior teeth, for a total of 358 endodontic treatments. None of the 
instruments showed signs of deformation, and only three instruments fractured during use, demonstrating a low incidence of fracture when reciprocating motion is used to prepare the root canal.

Currently, the Reciproc system is one of the most popular instruments in endodontics. Previous research suggests it provides excellent in vitro and in vivo results in several aspects, including mechanical properties, ${ }^{104,16,107,108}$ disinfection of root canals, ${ }^{109}$ root canal shaping, ${ }^{32,110}$ and postoperative pain. ${ }^{105,111,112}$ The Reciproc blue CM (VDW GmbH, Munich, Germany) thermally treated NiTi instruments are improved versions of the original Reciproc system. They provide increased resistance to cyclic fatigue and greater flexibility. ${ }^{96,113,114,115}$ The geometry, size, and design of Reciproc blue are the same as those of conventional Reciproc files; however, Reciproc blue has reduced microhardness while maintaining similar surface characteristics. ${ }^{114}$ The manufacturer recommends establishing a glide path before the use of Reciproc blue, as well as using a careful pecking motion to reach the working length. An additional improvement of Reciproc blue is the ability to pre-bend the instrument. ${ }^{113}$

The Wave One system consists of instruments with different cross-sections along the active part. They are described as modified convex triangular from tip to D8 (the eighth millimeter), with three cutting edges oriented counterclockwise, and triangular convex from D9 to D16. The taper is constant in the first three millimeters and decreases thereafter. This system was succeeded by Wave One Gold, which uses the Gold thermal process, with considerable improvement in strength and flexibility, ${ }^{116}$ in addition to greater resistance to torsional stress and flexibility compared to Reciproc and TF Adaptive files. ${ }^{117}$ The variability of tip diameters allows the clinician to prepare a wide range of apical diameters and root canal anatomies commonly found in daily practice, while the reduced taper ensures a more conservative preparation with greater dentin preservation at D16 (cervical region of the preparation). The WaveOne Gold design has four cutting edges with a rake angle of $85^{\circ}$, but only two edges are in permanent contact with the canal walls every 200 microns, which keeps the instrument centered on the longitudinal axis of the root canal. The Dentsply patented cross-section, in which only one cutting edge is in contact with the canal wall, decreases the contact area between the file and the canal wall, thus reducing taper lock. In conjunction with a constant rake angle of $24^{\circ}$ along the active part of the instrument, this design ensures little or no screw-in effect, as well as additional space to better remove debris. The tip of the WaveOne GOLD instrument is tapered and semi-active, modified to improve its penetration into any canal with a reproducible glide path. Together, these design features result in a very smooth reciprocal movement, eliminating the need to place any strain on the file, enhancing safety and greatly improving cutting capacity.

The X1 Blue File reciprocating system (MK Life, Porto Alegre, RS, Brazil) uses Blue heat treatment in its manufacturing. The system consists of three instruments with a triangular cross-section, a fixed taper of 0.6 , and tip diameters of \#20, \#25, and \#40. The manufacturer recommends that it be used in reciprocating motion with WaveOne programming.

\section{Combined movements (centric rotary + reciprocating)}

Some systems have been designed to combine rotary and reciprocating movements, taking advantage of each one. Ultradent, Sybron Endo, Easy and J Morita have presented proposals of engines or instrument systems capable of working in the root canal with both kinematics.

The Genius system (Ultradent, South Jordan, UT, USA), introduced in 2016, was developed for use in clockwise rotary and reciprocating $\left(90^{\circ}\right.$ clockwise, $30^{\circ}$ counterclockwise) motion. Canal preparation is first performed with reciprocating motion, which allows safer negotiation of the canal; then, symmetric rotary action is used to finish the preparation, guaranteeing greater efficiency in dentin removal from the canal and less extrusion of debris. Genius system instruments have an S-shaped cross-section with clockwise positive rake angles and are made from thermally treated NiTi alloy; however, there is no information in the literature regarding the type of heat treatment the system receives. A recent study conducted by Özyürek et al. ${ }^{118}$ showed that the Genius system was more resistant to torsional fracture compared to the Reciproc Blue 
and WaveOne Gold systems in doubly curved canals. Cavalli et al. ${ }^{119}$ found similar bacterial and endotoxin reductions in single-rooted teeth instrumented with the Mtwo, Reciproc, and Genius systems.

An innovative proposal was presented by Sybron Endo with the introduction of an Elements electric motor, capable of interpreting the load applied to the instrument during use and automatically switching from rotary to reciprocating motion when there is an increase in resistance to rotation. Once resistance is decreased, the handpiece returns to continuous rotary motion. During the continuous rotation cycle, the motor briefly stops every $600^{\circ}$ of advancement to allow the crystal lattice of the instrument to accommodate to the stresses. In the reciprocating cycle, the engine turns $370^{\circ}$ clockwise and $50^{\circ}$ counterclockwise. This provides the benefits of symmetric rotary motion, which cuts and ejects debris more easily, as well as those of reciprocating motion when loads on the instrument are highest, providing a significant reduction in fracture risk ${ }^{120}$. Its use is recommended for the Twisted File Adaptive System, a variation of the Twisted File system in which the instruments were rearranged into two sequences of three instruments each, one for wider canals and another for narrower ones. It has the same design characteristics, R-phase treatment, and twist-based manufacturing process with special surface conditioning. ${ }^{121}$

According to the manufacturer (J Morita MFG. CORP Kyoto, Japan), the Optimum Torque Reverse motion (OTR) was developed with the aim of to explore the benefits of symmetric reciprocating kinematics and minimize its disadvantages. During the continuous rotation in clockwise, the torque is automatically measured. So, if the torque presented was greater than a certain threshold previously defined, the instrument performs an oscillatory movement with 90 o in counterclockwise and clockwise. This process will be repeated until that the torque present lower than the threshold value and after, the continuous rotation is reestablished. This kinematics may be used with any NiTi system that present active cut angle in clockwise. Recently, Pèdulla et al. (2017) reported a greater resistance to cyclic fatigue of different instruments used in OTR movement compared to continuous rotation.

\section{Eccentric rotary motion}

Some systems, due to the characteristics of their instruments, rotate eccentrically or asymmetrically (i.e., the axis of rotation is off-center). These include the ProTaper Next system, with its asymmetrical rectangular cross-section, and XP-endo Shaper, which expands beyond the size of its core at temperatures equal to or greater than $35^{\circ} \mathrm{C}$.

The TRUShape system (Dentsply Sirona) also performs asymmetric rotary motion, due to the variable taper of the instruments and modified crosssection with an eccentric center of mass, such that only two points of the cross-section ever touch the dentin walls at any one time during canal preparation ${ }^{50,122}$. The instruments receive heat treatment after machining, and their long axis is S-shaped, with a triangular crosssection and a variable taper known as $.06 \mathrm{v}^{123}$. Thus, this system is especially recommended for canals with irregular geometries, because, in addition to enabling more conservative preparations, it simultaneously promotes a greater contact surface of the instrument with the canal walls ${ }^{124}$. In oval canals, this system was more effective at removing bacteria than the Twisted File system ${ }^{125}$.

\section{Transaxial motion}

With a design and kinematics completely different from those of existing systems, the SAF (Self-Adjusting File) instrument was developed by ReDent-Nova (Ra'anana, Israel) in 2010. This instrument is a hollow file in the shape of a cylindrical meshwork, made from a thin NiTi structure with an abrasive surface that is able to adapt to the walls of the root canal. The file operates coupled to a silicone irrigation device (VATEA, ReDent-Nova), which provides a continuous flow of irrigant during instrumentation. It is operated in an in-and-out pecking motion, while the handpiece vibrates vertically with a frequency of 3000 to 5000 vibrations/min and an amplitude of $0.4 \mathrm{~mm}$. Two 2-minute cycles are performed, for a total instrumentation time of 4 minutes per canal, which allows removal of a layer of dentin approximately 60 to $75 \mathrm{~mm}$ thick in the perimeter of the canal. The pecking movement, combined with the close circumferential contact of the file with the canal walls, removes dentin by abrasion. ${ }^{126}$ 


\section{Optimum Glide Path (OGP)}

This movement was also developed by J Morita company (J Morita MFG. CORP Kyoto, Japan) and may be used to reach the glide path and the foraminal patency. Rotary instruments with small size (\#10, \#15 and \#20) may be used with gentle movements of symmetric and asymmetric alternated rotation, simulating the partial enlargement and exploration. In OGP movement, the instrument used to glide path performs a symmetric oscillatory movement, followed by a clockwise rotation of $180 \mathrm{o}$. This combination of movements repeats

\section{Mechanical glide path instruments}

The combined use of stainless steel hand instruments and NiTi rotary instruments is recommended when establishing a glide path for curved and/or narrow canals ${ }^{127,128}$. While hand instruments provide tactile feedback on root canal anatomy, the superior flexibility and mechanical strength of NiTi instruments aim to reduce the occurrence of iatrogenic errors during root canal exploration. ${ }^{129,130,131}$ A pioneering proposal in this sense was the PathFile System (Dentsply Sirona), which consists of three instruments with tip diameters of 13,16 , and $19 \mathrm{~mm}$ and a standard .02 taper. The manufacturer recommends their use after establishing initial patency by hand with a \#10 K-file. The instruments have a quadrangular crosssection, which increases their torsional strength. ${ }^{127,132}$ In addition, the PathFile instruments have a reduced angle at the transition between the tip and the first cutting edge, which, coupled with the inactive tip, reduces the possibility of apical transportation. ${ }^{133}$ Nakagawa et al. ${ }^{134}$ demonstrated that PathFile instruments have greater flexibility than Scout Race instruments, which are also intended for glide path use.

The ProGlider instrument (Dentsply Sirona) is manufactured by machining a NiTi M-Wire, which gives the instrument great flexibility and flexural strength. Rotary instrumentation with the ProGlider instrument, which has a progressive taper (2-8\%), ensures wider pre-enlargement compared to a \#15 K-file, which facilitates advancement of subsequent rotary instruments. ${ }^{130,135}$ Paleker and van der Vyver ${ }^{136}$ also found better centering of the preparation after initial instrumentation with the ProGlider when compared to manual instruments in teeth with moderately curved canals. Elnaghy and Elsaka ${ }^{137}$ reported greater flexibility and resistance to cyclic and torsional fatigue with the ProGlider system as compared with PathFile instruments of the same diameter (16/.02).

The RaCe system is also available in series intended exclusively for establishing a glide path. The ScoutRace and Race ISO 10 instruments provide initial access to the canal faster than stainless steel handfiles, and have greater cyclic fatigue resistance and flexibility ${ }^{138}$. The ScoutRace sequence is composed of three instruments $(\# 10$, \#15, and \#20), with a square cross section and .02 taper, while the Race ISO 10 series consists of \#10 instruments with $.02, .04$, and .06 taper. ${ }^{134}$

Several options are also available for establishing a glide path for reciprocating instrumentation. The R-Pilot instruments were recently developed to be used in the glide path procedure, providing the final cut of dentin in the counterclockwise (CCW) direction. The instrument is made from M-Wire alloy, with an inactive tip, a diameter of $12.5 \mathrm{~mm}$, a constant 0.04 taper and an S-shaped cross-section. According to the manufacturer, R-Pilot files only should be used after exploration of the root canal with a \#08 file down to the working length. Uslu et al. ${ }^{139}$ found that R-Pilot NiTi glide path files, when used with a reciprocating motion, had excellent cyclic fatigue resistance in an artificial S-shaped canal. Only limited scientific information about these instruments is available. The WaveOne Gold Glider is a single-file glide path system with the same Gold treatment, parallelogram cross-section, and reciprocating motion of WaveOne shaping files. With a progressively tapered design over the active portion (from $2 \%$ to over $6 \%$ ), the potential for taper lock and screw-in effect is reduced. According to the manufacturer, compared to hand files, WaveOne Gold Glider offers increased ability to navigate narrow and curved canals. There is currently no published research regarding the WaveOne Gold Glider system.

Recently, the Pre-SAF rotary instruments were introduced for the specific purpose of glide path preparation before use of the Self-Adjusting File system. According to Metzger, ${ }^{140}$ the Pre-SAF 
instruments include the Pre-SAF OS (orifice shaper, sized \#40/.10), the Pre-SAF 1 (for narrow canals, sized \#15/.02), and the Pre-SAF 2 (creates a glide path for the SAF $1.5 \mathrm{~mm}$, sized \#20/.04). ${ }^{141}$

\section{Final considerations}

Technological advancements achieved in recent years have enabled major progress in endodontic therapy. The introduction of nickel-titanium alloys and the automation of endodontic instrumentation was a huge leap forward, breaking the nearly 200year paradigm of purely manual instrumentation. Nevertheless, the practice of root canal instrumentation has remained in a constant state of flux, whether due to development of new instruments with different designs or to further advances in NiTi alloy treatments, continuously seeking to obtain more resilient and flexible systems. The incorporation of new motion strategies (reciprocating or combined) has reduced the risk of instrument separation.

Recent studies are also unanimous in stating that a considerable percentage of walls are never touched during root canal preparation with centric or reciprocating rotary instruments. Conversely, eccentric rotary motion, because it produces more balanced points of contact with the root dentin, contributes to greater instrument cyclic fatigue resistance and ensures greater contact with the canal walls.

The current literature reflects a trend towards the use of NiTi alloys with heat treatment and controlled memory, designed to increase the flexibility and reduce the shape-memory properties of instruments. In clinical practice, these instruments can be pre-bent and maintain this flexed shape, facilitating penetration at the entrance of the root canal, which is in keeping with more conservative approaches to access surgery. $\mathrm{CM}$ instruments also have a higher deformation capacity before fracture than conventional instruments, due to their greater flexibility and cyclic fatigue resistance.

To date, there is still no endodontic instrument capable of meeting all of the requirements of an optimal root canal preparation. New materials and studies must be developed in the continued search for a system that can combine efficiency and safety in endodontic instrumentation.

\section{References}

1. Auricchio F, Taylor R, Lubliner J. Shape

memory alloys: macromodelling and numerical simulations of the superelastic behavior. Comp Meth Appl Mech Eng. 1997;146(3-4):281-312. https://doi.org/10.1016/S0045-7825(96)01232-7

2. Andreasen GF, Hilleman TB. An evaluation of 55 cobalt substituted Nitinol wire for use in orthodontics. J Am Dent Assoc. 1971 Jun;82(6):1373-5. https://doi.org/10.14219/jada.archive.1971.0209

3. Civjan S, Huget EF, DeSimon LB. Potential applications of certain nickel-titanium (nitinol) alloys. J Dent Res. 1975 Jan-Feb;54(1):89-96. https://doi.org/10.1177/00220345750540014301

4. Walia HM, Brantley WA, Gerstein H. An initial investigation of the bending and torsional properties of Nitinol root canal files. J Endod. 1988 Jul;14(7):346-51. https://doi.org/10.1016/S0099-2399(88)80196-1

5. Thompson SA. An overview of nickel-titanium alloys used in dentistry. Int Endod J. 2000 Jul;33(4):297-310. https://doi.org/10.1046/j.1365-2591.2000.00339.x
6. Otsuka K, Wayman CM. Shape memory materials. Cambrigdge: Cambridge Univ. Press; 1998. Cap 1, Introduction; p.1-26.

7. Nasser SN, Guo WG. Superelastic and cyclic response of NiTi SMA at various strain rates and temperatures. Mech Mater. 2006;38(5-6):463-74. https://doi.org/10.1016/i.mechmat.2005.07.004

8. Otsuka K, Ren X. Physical metallurgy of Ti-Ni-based shape memory alloys. Prog Mater Sci. 2005;50(5):511-678. https://doi.org/10.1016/i.pmatsci.2004.10.001

9. Miura F, Mogi M, Ohura Y, Hamanaka H. The super-elastic property of the Japanese NiTi alloy wire for use in orthodontics. Am J Orthod Dentofacial Orthop. 1986 Jul;90(1):1-10. https://doi.org/10.1016/0889-5406(86)90021-1

10. Miyazaki S, Suizu K, Otsuka K, Takashima T. Effect of various factors on fatigue crack propagation rate in Ti-Ni alloys. MRS International Meeting on Adv Mater. 1989;9:263-268.

11. Shen Y, Haapasalo M. Three-dimensional analysis of cutting behavior of nickel-titanium rotary instruments by microcomputed tomography. J Endod. 2008 May;34(5):60610. https://doi.org/10.1016/i.joen.2008.02.025 
12. Ruddle CJ. The ProTaper technique.

Endod Topics. 2005;10(1):187-90.

https://doi.org/10.1111/j.1601-1546.2005.00115.x

13. Gambarini G, Grande NM, Plotino G, Somma F, Garala

$M$, De Luca $M$, et al. Fatigue resistance of engine-driven

rotary nickel-titanium instruments produced by new manufacturing methods. J Endod. 2008 Aug;34(8):1003-5.

https://doi.org/10.1016/i.joen.2008.05.007

14. Kim HC, Cheung GS, Lee CJ, Kim BM, Park JK, Kang SI. Comparison of forces generated during root canal shaping and residual stresses of three nickeltitanium rotary files by using a three-dimensional finiteelement analysis. J Endod. 2008 Jun;34(6):743-7. https://doi.org/10.1016/j.joen.2008.03.015

15. Plotino G, Grande NM, Falanga A, Di Giuseppe IL, Lamorgese V, Somma F. Dentine removal in the coronal portion of root canals following two preparation techniques. Int Endod J. 2007 Nov;40(11):852-8. https://doi.org/10.1111/j.1365-2591.2007.01284.x

16. Veltri M, Mollo A, Mantovani L, Pini P, Balleri P, Grandini S. A comparative study of Endoflare-Hero Shaper and Mtwo NiTi instruments in the preparation of curved root canals. Int Endod J. 2005 Sep;38(9):610-6. https://doi.org/10.1111/i.1365-2591.2005.00989.x

17. Bürklein S, Schäfer E. Apically extruded debris with reciprocating single-file and full-sequence rotary instrumentation systems. J Endod. 2012 Jun;38(6):850-2. https://doi.org/10.1016/j.joen.2012.02.017

18. Ha JH, Kwak SW, Kim SK, Kim HC. Screw-in forces during instrumentation by various file systems. Restor Dent Endod. 2016 Nov;41(4):304-9. https://doi.org/10.5395/rde.2016.41.4.304

19. Schäfer E, Erler M, Dammaschke T. Comparative study on the shaping ability and cleaning efficiency of rotary Mtwo instruments. Part 1. Shaping ability in simulated curved canals. Int Endod J. 2006 Mar;39(3):196-202. https://doi.org/10.1111/i.1365-2591.2006.01074.x

20. Shivashankar MB, Niranjan NT, Jayasheel A, Kenchanagoudra MG. Computed Tomography Evaluation of Canal Transportation and Volumetric Changes in Root Canal Dentin of Curved Canals Using Mtwo, ProTaper and ProTaper Next Rotary System-An In-vitro Study. J Clin Diagn Res. 2016 Nov;10(11):ZC10-ZC14. doi: 10.7860/JCDR/2016/20373.8788

21. Gambarini G, Plotino G, Grande NM, AlSudani D, De Luca M, Testarelli L. Mechanical properties of nickel-titanium rotary instruments produced with a new manufacturing technique. Int Endod J. 2011 Apr;44(4):337-41. https://doi.org/10.1111/j.1365-2591.2010.01835.x

22. Shen Y, Qian W, Abtin H, Gao Y, Haapasalo M. Fatigue testing of controlled memory wire nickel-titanium rotary instruments. J Endod. 2011 Jul;37(7):997-1001. https://doi.org/10.1016/j.joen.2011.03.023
23. Gutmann JL, Gao Y. Alteration in the inherent metallic and surface properties of nickel-titanium root canal instruments to enhance performance, durability and safety: a focused review. Int Endod J. 2012 Feb;45(2):113-28. https://doi.org/10.1111/j.1365-2591.2011.01957.x

24. Ye J, Gao Y. Metallurgical characterization of M-Wire nickeltitanium shape memory alloy used for endodontic rotary instruments during low-cycle fatigue [Send to]. J Endod. 2012 Jan;38(1):105-7. https://doi.org/10.1016/i.joen.2011.09.028

25. Anderson ME, Price JW, Parashos P. Fracture resistance of electropolished rotary nickel-titanium endodontic instruments. J Endod. 2007 Oct;33(10):1212-6. https://doi.org/10.1016/i.joen.2007.07.007

26. Gao Y, Gutmann JL, Wilkinson K, Maxwell R, Ammon $D$. Evaluation of the impact of raw materials on the fatigue and mechanical properties of ProFile Vortex rotary instruments. J Endod. 2012 Mar;38(3):398-401. https://doi.org/10.1016/i.joen.2011.11.004

27. Schäfer $E$, Vlassis M. Comparative investigation of two rotary nickel-titanium instruments: ProTaper versus RaCe. Part 2. Cleaning effectiveness and shaping ability in severely curved root canals of extracted teeth. Int Endod J. 2004 Apr;37(4):23948. https://doi.org/10.1111/i.0143-2885.2004.00783.x

28. Saber SE, Nagy MM, Schäfer E. Comparative evaluation of the shaping ability of ProTaper Next, iRaCe and Hyflex CM rotary NiTi files in severely curved root canals. Int Endod J. 2015 Feb;48(2):131-6. https://doi.org/10.1111/iej.12291

29. Pasternak B Jrl, Sousa Neto MD, Dionísio VC, Pécora JD, Silva RG. Analysis of kinematic, kinetic and electromyographic patterns during root canal preparation with rotary and manual instruments. J Appl Oral Sci. 2012 Feb;20(1):57-63.

30. García M, Duran-Sindreu F, Mercadé M, Bueno R, Roig M. A comparison of apical transportation between ProFile and RaCe rotary instruments. J Endod. 2012 Jul;38(7):990-2. https://doi.org/10.1016/i.joen.2012.03.022

31. Nabavizadeh M, Abbaszadegan A, Khojastepour $L$, Amirhosseini M, Kiani E. A Comparison of Apical Transportation in Severely Curved Canals Induced by Reciproc and BioRaCe Systems. Iran Endod J. 2014;9(2):117-22.

32. Busquim S, Cunha RS, Freire L, Gavini G, Machado ME, Santos M. A micro-computed tomography evaluation of long-oval canal preparation using reciprocating or rotary systems. Int Endod J. 2015 Oct;48(10):1001-6. https://doi.org/10.1111/iej.12398

33. Bürklein S, Mathey D, Schäfer E. Shaping ability of ProTaper NEXT and BT-RaCe nickel-titanium instruments in severely curved root canals. Int Endod J. 2015 Aug;48(8):774-81. https://doi.org/10.1111/iej.12375PMID:25156248

34. Brasil SC, Marceliano-Alves MF, Marques ML, Grillo JP, Lacerda MF, Alves FR, et al. Canal Transportation, Unprepared Areas, and Dentin Removal after Preparation with BT-RaCe and ProTaper Next Systems. J Endod. 2017 Oct;43(10):16837. https://doi.org/10.1016/i.joen.2017.04.012PMID:28712638 
35. Viana AC, Chaves Craveiro de Melo M, Guiomar de Azevedo Bahia M, Lopes Buono VT. Relationship between flexibility and physical, chemical, and geometric characteristics of rotary nickel-titanium instruments. Oral Surg Oral Med Oral Pathol Oral Radiol Endod. 2010 Oct;110(4):527-33. https://doi.org/10.1016/i.tripleo.2010.05.006

36. Wealleans JA, Kirkpatrick TC, Rutledge RE. The effects of dentin debris on the cyclic fatigue resistance of several nickel titanium rotary systems. Oral Surg Oral Med Oral Pathol Oral Radiol Endod. 2011 Sep;112(3):390-5. https://doi.org/10.1016/j.tripleo.2011.01.032

37. Ray JJ, Kirkpatrick TC, Rutledge RE. Cyclic fatigue of EndoSequence and $\mathrm{K} 3$ rotary files in a dynamic model. J Endod. 2007 Dec;33(12):1469-72. https://doi.org/10.1016/i.joen.2007.07.041

38. Testarelli L, Plotino G, Al-Sudani D, Vincenzi V, Giansiracusa A, Grande NM, et al. Bending properties of a new nickel-titanium alloy with a lower percent by weight of nickel. J Endod. 2011 Sep;37(9):1293-5. https://doi.org/10.1016/i.joen.2011.05.023

39. Viana AC, Pereira ES, Bahia MG, Buono VT. The influence of simulated clinical use on the flexibility of rotary ProTaper Universal, K3 and EndoSequence nickeltitanium instruments. Int Endod J. 2013 Sep;46(9):855-62. https://doi.org/10.1111/iej.12071

40. Freire LG, Gavini G, Branco-Barletta F, SanchesCunha R, dos Santos M. Microscopic computerized tomographic evaluation of root canal transportation prepared with twisted or ground nickel-titanium rotary instruments. Oral Surg Oral Med Oral Pathol Oral Radiol Endod. 2011 Dec;112(6):e143-8. https://doi.org/10.1016/j.tripleo.2011.06.029

41. Williamson AE, Sandor AJ, Justman BC. A comparison of three nickel titanium rotary systems, EndoSequence, ProTaper universal, and profile GT, for canalcleaning ability. J Endod. 2009 Jan;35(1):107-9. https://doi.org/10.1016/i.joen.2008.09.022

42. Nabeshima CK, Caballero-Flores H, Cai S, Aranguren J, Borges Britto ML, Machado ME. Bacterial removal promoted by 2 single-file systems: Wave One and One Shape. J Endod. 2014 Dec;40(12):1995-8. https://doi.org/10.1016/i.joen.2014.07.024

43. Dhingra A, Kochar R, Baneriee S, Srivastava P. Comparative evaluation of the canal curvature modifications after instrumentation with One Shape rotary and Wave One reciprocating files. J Conserv Dent. 2014 Mar;17(2):138-41. https://doi.org/10.4103/0972-0707.128049

44. Neelakantan P, Reddy P, Gutmann JL. Cyclic fatigue of two different single files with varying kinematics in a simulated double-curved canal. J Investig Clin Dent. 2016 Aug;7(3):272-7. https://doi.org/10.1111/jicd.12159

45. Liu Y, Chen X, Mc Cormick PG. Effect of low temperature ageing on the transformation behavior of near- equiatomic NiTi. J Mater Sci. 1997;32(22):5979-84. https://doi.org/10.1023/A:1018615127911

46. Bahia MG, Martins RC, Gonzalez BM, Buono VT. Physical and mechanical characterization and the influence of cyclic loading on the behaviour of nickel-titanium wires employed in the manufacture of rotary endodontic instruments. Int Endod J. 2005 Nov;38(11):795-801. https://doi.org/10.1111/i.1365-2591.2005.01016.x

47. Miyazaki S, Ohmi Y, Otsuka K, Suzuki Y. Characteristics of deformation and transformation pseudo elasticity in $\mathrm{Ti}-\mathrm{Ni}$ alloys. J Phys (Paris). 1982;43 suppl 12:255-60.

48. Gambarini G, Gerosa R, De Luca M, Garala M, Testarelli L. Mechanical properties of a new and improved nickel-titanium alloy for endodontic use: an evaluation of file flexibility. Oral Surg Oral Med Oral Pathol Oral Radiol Endod. 2008a Jun;105(6):798-800. https://doi.org/10.1016/i.tripleo.2008.02.017

49. Johnson E, Lloyd A, Kuttler S, Namerow K. Comparison between a novel nickel-titanium alloy and 508 nitinol on the cyclic fatigue life of ProFile 25/.04 rotary instruments. J Endod. 2008 Nov;34(11):1406-9. https://doi.org/10.1016/i.joen.2008.07.029

50. Elnaghy AM, Elsaka SE. Assessment of the mechanical properties of ProTaper Next Nickel-titanium rotary files. J Endod. 2014 Nov; 40(11):1830-4. https://doi.org/10.1016/i.joen.2014.06.011

51. Uygun AD, Kol E, Topcu MK, Seckin F, Ersoy I, Tanriver $M$. Variations in cyclic fatigue resistance among ProTaper Gold, ProTaper Next and ProTaper Universal instruments at different levels. Int Endod J. 2016 May;49(5):494-9. https://doi.org/10.1111/iej.12471

52. Gao Y, Shotton V, Wilkinson K, Phillips G, Johnson WB. Effects of raw material and rotational speed on the cyclic fatigue of ProFile Vortex rotary instruments. J Endod. 2010 Jul;36(7):1205-9. https://doi.org/10.1016/i.joen.2010.02.015

53. Bouska J, Justman B, Williamson A, DeLong C, Qian F. Resistance to cyclic fatigue failure of a new endodontic rotary file. J Endod. 2012 May;38(5):667-9. https://doi.org/10.1016/i.joen.2012.01.016

54. Bardsley S, Peters $\mathrm{Cl}$, Peters $\mathrm{OA}$. The effect of three rotational speed settings on torque and apical force with vortex rotary instruments in vitro. J Endod. 2011 Jun;37(6):860-4 https://doi.org/10.1016/i.joen.2011.01.022

55. Rhodes SC. Hülsmann M, McNeal SF, Beck P, Eleazer PD. Comparisson of root canal preparation using reciprocating Safesiders stainless steel and Vortex nickel-titanium instruments. Oral Surg Oral Med Oral Pathol Oral Radiol Endod. 2011 May;111(5):659-67. https://doi.org/10.1016/j.tripleo.2010.11.021

56. Gambarini G, Testarelli L, Galli M, Tucci E, De Luca M. The effect of a new finishing process on the torsional resistance of twisted nickel-titanium rotary instruments. Minerva Stomatol. 2010 Jul-Aug;59(7-8):401-6. 
57. Rodrigues RC, Lopes HP, Elias CN, Amaral G, Vieira $V T$, De Martin AS. Influence of different manufacturing methods on the cyclic fatigue of rotary nickel-titanium endodontic instruments. J Endod. 2011 Nov;37(11):1553-7. https://doi.org/10.1016/j.joen.2011.08.011

58. Shen Y, Zhou H, Campbell L, Wang Z, Wang R, Du T et al. Fatigue and nanomechanical properties of K3XF nickeltitanium instruments. Int Endod J. 2014 Dec;47(12):1160-7. https://doi.org/10.1111/iej.12265

59. Huang $X$, Shen $Y$, Wei $X$, Haapasalo M. Fatigue resistance of nickel-titanium instruments exposed to high-concentration hypochlorite. J Endod. 2017 Nov;43(11):1847-51. https://doi.org/10.1016/i.joen.2017.06.033

60. Mounce RE. A new method of canal enlargement. Dent Today. 2008 May;27(5):94.

61. Pérez-Higueras JJ, Arias A, Macorra JC. Cyclic fatigue resistance of $\mathrm{K} 3, \mathrm{~K} 3 \mathrm{XF}$, and twisted file nickel-titanium files under continuous rotation or reciprocating motion. J Endod. 2013 Dec;39(12):1585-8. https://doi.org/10.1016/i.joen.2013.07.020

62. Elsaka SE, Elnaghy AM. Cyclic fatigue resistance of OneShape and WaveOne instruments using different angles of curvature. Dent Mater J. 2015;34(3):358-63. https://doi.org/10.4012/dmi.2014-252

63. Pereira ÉS, Viana AC, Buono VT, Peters OA, Bahia MG. Behavior of nickel-titanium instruments manufactured with different thermal treatments. J Endod. 2015 Jan;41(1):67-71. https://doi.org/10.1016/i.joen.2014.06.005PMID:25112810

64. Pereira ES, Singh R, Arias $A$, Peters $O A$. In vitro assessment of torque and force generated by novel ProTaper Next Instruments during simulated canal preparation. J Endod. 2013 Dec;39(12):1615-9. https://doi.org/10.1016/i.joen.2013.07.014

65. Zinelis S, Eliades T, Eliades G. A metallurgical characterization of ten endodontic $\mathrm{Ni}$ - $\mathrm{Ti}$ instruments: assessing the clinical relevance of shape memory and superelastic properties of $\mathrm{Ni}-\mathrm{Ti}$ endodontic instruments. Int Endod J. 2010 Feb;43(2):125-34. https://doi.org/10.1111/j.1365-2591.2009.01651.x

66. Kishore A, Gurtu A, Bansal R, Singhal A, Mohan S, Mehrotra A. Comparison of canal transportation and centering ability of Twisted Files, HyFlex controlled memory, and Wave One using computed tomography scan: an in vitro study. J Conserv Dent. 2017 May-Jun;20(3):161-5. https://doi.org/10.4103/JCD.JCD_110_16

67. Pinheiro SR, Alcalde MP, Vivacqua-Gomes N, Bramante $C M$, Vivan RR, Duarte MA et al. Evaluation of apical transportation and centring ability of five thermally treated NiTi rotary systems. Int Endod J. 2017 Nov.

68. Shen Y, Zhou HM, Wang Z, Campbell L, Zheng YF, Haapasalo M. Phase transformation behavior and mechanical properties of thermomechanically treated K3XF nickel-titanium instruments. J Endod. 2013 Jul;39(7):919-23. https://doi.org/10.1016/i.joen.2013.04.004
69. Santos LA, Bahia MG, de Las Casas EB, Buono VT. Comparison of the mechanical behavior between controlled memory and superelastic nickel-titanium files via finite element analysis. J Endod. 2013 Nov;39(11):1444-7. https://doi.org/10.1016/i.joen.2013.07.030

70. de Vasconcelos RA, Murphy S, Carvalho CA, Govindjee RG, Govindjee S, Peters OA. Evidence for Reduced Fatigue Resistance of Contemporary Rotary Instruments Exposed to Body Temperature. J Endod. 2016 May;42(5):782-7. https://doi.org/10.1016/i.joen.2016.01.025

71. Pereira AG, Fagundes dos Santos RM, Mendes Azevedo KC, Raposo LH, Biffi JC. Assessment of influence of flexion angles of files in apical stop preparation by using manual and rotary instrumentation techniques. J Endod. 2012 Oct;38(10):13836. https://doi.org/10.1016/i.joen.2012.06.041

72. Bürklein S, Böries L, Schäfer E. Comparison of preparation of curved root canals with Hyflex CM and Revo-S rotary nickeltitanium instruments. Int Endod J. 2014 May;47(5):470-6. https://doi.org/10.1111/iej.12171

73. Zhao D, Shen Y, Peng B, Haapasalo M. Micro-computed tomography evaluation of the preparation of mesiobuccal root canals in maxillary first molars with Hyflex CM, Twisted Files, and K3 instruments. J Endod. 2013 Mar;39(3):385-8. https://doi.org/10.1016/i.joen.2012.11.030

74. Capar ID, Ertas H, Arslan H. Comparison of cyclic fatigue resistance of nickel-titanium coronal flaring instruments. J Endod. 2014 Aug;40(8):1182-5. https://doi.org/10.1016/i.joen.2013.12.031

75. Al-Sudani D. Topographic Analysis of HyFlex $(\circledR)$ Controlled Memory Nickel-Titanium Files. J Int Oral Health. 2014 NovDec;6(6):1-4

76. Alfogom Alazemi M, Bryant ST, Dummer PM. Deformation of HyFlex CM instruments and their shape recovery following heat sterilization. Int Endod J. 2015 Jun;48(6):593-601. https://doi.org/10.1111/iej.12353

77. Pirani C, lacono F, Generali L, Sassatelli P, Nucci C, Lusvarghi $L$, et al. HyFlex EDM: superficial features, metallurgical analysis and fatigue resistance of innovative electro discharge machined NiTi rotary instruments. Int Endod J. 2016 May;49(5):483-93. https://doi.org/10.1111/iej.12470

78. Theisen W, Schuermann A. Electro discharge machining of nickeltitanium shape memory alloys. Mater Sci Eng A. 2004;378(12):200-4. https://doi.org/10.1016/i.msea.2003.09.115

79. Pernot J, Rolland X, Euvrard H. Endodontic instrument with rough surfaces, and method for producing such an instrument. Patent Application WO2015028743 A1. 2015.

80. Pedullà E, Lo Savio F, Boninelli S, Plotino G, Grande NM, La Rosa $G$ et al. Torsional and cyclic fatigue resistance of a new nickel-titanium instrument manufactured by electrical discharge machining. J Endod. 2016 Jan;42(1):156-9. https://doi.org/10.1016/i.joen.2015.10.004

81. lacono F, Pirani C, Generali L, Bolelli G, Sassatelli P, Lusvarghi L et al. Structural analysis of HyFlex EDM instruments. Int Endod J. 2017 Mar;50(3):303-13. https://doi.org/10.1111/iej.12620 
82. Arias A, Macorra JC, Govindjee S, Peters OA. Correlation between Temperature-dependent Fatigue Resistance and Differential Scanning Calorimetry Analysis for 2 Contemporary Rotary Instruments. J Endod. 2018 Apr;44(4):630-4. https://doi.org/10.1016/i.joen.2017.11.022

83. Uslu G, Özyürek T, Yılmaz K. Comparison of alterations in the surface topographies of HyFlex CM and HyFlex EDM nickel-titanium files after root canal preparation: a threedimensional optical profilometry study. J Endod. 2018 Jan;44(1):115-9. https://doi.org/10.1016/i.joen.2017.05.023

84. Menezes SE, Batista SM, Lira JO, Monteiro GQM. Cyclic fatigue resistance of waveone gold, prodesign $\mathrm{R}$ and prodesign logic files in curved canals in vitro. Iran Endod J. 2017;12(4):468-73. PMID:29225643

85. Shen Y, Qian W, Abtin H, Gao Y, Haapasalo $M$. Effect of environment on fatigue failure of controlled memory wire nickel-titanium rotary instruments. J Endod. 2012 Mar;38(3):376-80. https://doi.org/10.1016/i.joen.2011.12.002

86. Peters OA, Gluskin AK, Weiss RA, Han JT. An in vitro assessment of the physical properties of novel Hyflex nickeltitanium rotary instruments. Inter Endod J. 2012(45):1027-34.

87. Acosta EC, Resende PD, Peixoto IF, Pereira ÉS, Buono VT, Bahia MG. Influence of cyclic flexural deformation on the torsional resistance of controlled memory and conventional nickel-titanium instruments. J Endod. 2017 Apr;43(4):613-8. https://doi.org/10.1016/i.joen.2016.11.007

88. Shen Y, Hieawy A, Huang X, Wang ZJ, Maezono H, Haapasalo M. Fatigue Resistance of a 3 -dimensional Conforming Nickel-Titanium Rotary Instrument in Double Curvatures. J Endod. 2016 Jun;42(6):961-4. https://doi.org/10.1016/i.joen.2016.02.012

89. VDW Brochure. Product information and Technical service. https://www.vdw-dental.com/en/products/preparation/

90. Plotino G, Grande NM, Cotti E, Testarelli L, Gambarini G. Blve treatment enhances cyclic fatigue resistance of vortex nickel-titanium rotary files. J Endod. 2014 Sep;40(9):1451-3. https://doi.org/10.1016/i.joen.2014.02.020

91. Nguyen HH, Fong H, Paranipe A, Flake NM, Johnson JD, Peters OA. Evaluation of the resistance to cyclic fatigue among ProTaper Next, ProTaper Universal, and Vortex Blue rotary instruments. J Endod. 2014 Aug;40(8):1190-3. https://doi.org/10.1016/i.joen.2013.12.033

92. Gagliardi J, Versiani MA, de Sousa-Neto MD, Plazas-Garzon A, Basrani B. Evaluation of the shaping characteristics of ProTaper Gold, ProTaper NEXT, and ProTaper universal in curved canals. J Endod. 2015 Oct;41(10):1718-24. https://doi.org/10.1016/j.joen.2015.07.009

93. Azim AA, Aksel H, Zhuang T, Mashtare T, Babu JP, Huang GT. Efficacy of 4 irrigation protocols in killing bacteria colonized in dentinal tubules examined by a novel confocal laser scanning microscope analysis. J Endod. 2016 Jun;42(6):928-34. https://doi.org/10.1016/j.joen.2016.03.009
94. Bao P, Shen Y, Lin J, Haapasalo M. In Vitro Efficacy of XPendo Finisher with 2 Different Protocols on Biofilm Removal from Apical Root Canals. J Endod. 2017 Feb;43(2):321-5. https://doi.org/10.1016/i.joen.2016.09.021

95. Leoni GB, Versiani MA, Silva-Sousa YT, Bruniera JF, Pécora $J D$, Sousa-Neto MD. Ex vivo evaluation of four final irrigation protocols on the removal of hard-tissue debris from the mesial root canal system of mandibular first molars. Int Endod J. 2017 Apr;50(4):398-406. https://doi.org/10.1111/iej.12630

96. Keskin C, Sariyilmaz E, Sariyilmaz Ö. Efficacy of XP-endo Finisher File in Removing Calcium Hydroxide from Simulated Internal Resorption Cavity. J Endod. 2017 Jan;43(1):126-30. https://doi.org/10.1016/i.joen.2016.09.009

97. Azim AA, Piasecki L, da Silva Neto UX, Cruz AT, Azim KA. XP Shaper, A Novel Adaptive Core Rotary Instrument: Micro-computed Tomographic Analysis of Its Shaping Abilities. J Endod. 2017 Sep;43(9):1532-8. https://doi.org/10.1016/i.joen.2017.04.022

98. Lacerda MF, Marceliano-Alves MF, Pérez AR, Provenzano JC, Neves MA, Pires FR, et al. Cleaning and shaping oval canals with 3 instrumentation systems: a correlative micro-computed tomographic and histologic study. J Endod. 2017 Nov;43(11):1878-84. https://doi.org/10.1016/i.joen.2017.06.032

99. Elnaghy A, Elsaka S. Cyclic fatigue resistance of XP-endo Shaper compared with different nickel-titanium alloy instruments. Clin Oral Investig. 2018 Apr;22(3):1433-7. https://doi.org/10.1007/s00784-017-2245-5

100. Silva EJ, Vieira VT, Belladonna FG, Zuolo AS, Antunes HD, Cavalcante DM, et al. Cyclic and Torsional Fatigue Resistance of XP-endo Shaper and TRUShape Instruments. J Endod. 2018 Jan;44(1):168-72. https://doi.org/10.1016/i.joen.2017.08.033

101. Elnaghy AM, Elsaka SE. Torsional resistance of XP-endo Shaper at body temperature compared with several nickel-titanium rotary instruments. Int Endod J. 2018 May;51(5):572-6. https://doi.org/10.1111/iej.12700

102. Özyürek T, Gündoğar M, Uslu G, Yılmaz K, Staffoli S, Nm $G$, Plotino G, Polimeni A. Cyclic fatigue resistances of Hyflex EDM, WaveOne gold, Reciproc blue and 2shape NiTi rotary files in different artificial canals. Odontology. 2018 Jan. https://doi.org/10.1007/s10266-018-0340-y

103. Yared G. Canal preparation using only one $\mathrm{Ni}$ Ti rotary instrument: preliminary observations. Int Endod J. 2008 Apr;41(4):339-44. https://doi.org/10.1111/j.1365-2591.2007.01351.x

104. Gavini G, Caldeira CL, Akisue E, Candeiro GT, Kawakami DA. Resistance to flexural fatigue of Reciproc R25 files under continuous rotation and reciprocating movement. J Endod. 2012 May;38(5):684-7. https://doi.org/10.1016/i.joen.2011.12.033

105. Bueno CS, Oliveira DP, Pelegrine RA, Fontana CE, Rocha $D G$, Bueno CE. Fracture incidence of waveone and reciproc files during root canal preparation of up to 3 posterior teeth: a prospective clinical study. J Endod. 2017 May;43(5):705-8. https://doi.org/10.1016/i.joen.2016.12.024 
106. Plotino G, Ahmed HM, Grande NM, Cohen S, Bukiet F. Current assessment of reciprocation in endodontic preparation: a comprehensive review. Part II: Properties and effectiveness. J Endod. 2015 Dec;41(12):1939-50. https://doi.org/10.1016/i.joen.2015.08.018

107. Scelza P, Harry D, Silva LE, Barbosa IB, Scelza MZ. A comparison of two reciprocating instruments using bending stress and cyclic fatigue tests. Braz Oral Res. 2015;29(1):1-7. https://doi.org/10.1590/1807-3107BOR-2015.vol29.0107

108. Ahn SY, Kim HC, Kim E. kinematic effects of nickel-titanium instruments with reciprocating or continuous rotation motion: a systematic review of in vitro studies. J Endod. $2016 \mathrm{Jul}$;42(7):1009-17. https://doi.org/10.1016/j.joen.2016.04.002

109. Nakamura VC, Candeiro GT, Cai S, Gavini $G$. Ex vivo evaluation of three instrumentation techniques on $\mathrm{E}$. faecalis biofilm within oval shaped root canals. Braz Oral Res. 2015;29(1):1-7. https://doi.org/10.1590/1807-3107BOR-2015.vol29.0027

110. Espir CG, Nascimento-Mendes CA, GuerreiroTanomaru JM, Freire LG, Gavini G, Tanomaru-Filho M. Counterclockwise or clockwise reciprocating motion for oval root canal preparation: a micro-CT analysis. Int Endod J. 2018 May;51(5):541-8. https://doi.org/10.1111/iej.12776

111. Cruz Junior JA, Coelho MS, Kato AS, VivacquaGomes N, Fontana CE, Rocha DG et al. The effect of foraminal enlargement of necrotic teeth with the reciproc system on postoperative pain: a prospective and randomized clinical trial. J Endod. 2016 Jan;42(1):8-11. https://doi.org/10.1016/i.joen.2015.09.018

112. Kherlakian D, Cunha RS, Ehrhardt IC, Zuolo ML, Kishen A, Bueno CES. Comparison of the incidence of postoperative pain after using 2 reciprocating systems and a continuous rotary system: a prospective randomized clinical trial. J Endod. 2016 Feb;42(2):171-6. https://doi.org/10.1016/j.joen.2015.10.011

113. Adıgüzel M, Capar ID. Comparison of cyclic fatigue resistance of waveone and waveone gold small, primary, and large instruments. J Endod. 2017 Apr;43(4):623-7. https://doi.org/10.1016/i.joen.2016.11.021

114. De-Deus G, Silva EJ, Vieira VT, Belladonna FG, Elias $C N$, Plotino $G$ et al. Blue thermomechanical treatment optimizes fatigue resistance and flexibility of the reciproc files. J Endod. 2017 Mar;43(3):462-6. https://doi.org/10.1016/i.joen.2016.10.039

115. Topçuoğlu HS, Düzgün S, Akłı A, Topçuoğlu G. Laboratory comparison of cyclic fatigue resistance of WaveOne Gold, Reciproc and WaveOne files in canals with a double curvature. Int Endod J. 2017 Jul;50(7):713-7. https://doi.org/10.1111/iej.12674

116. Arslan H, Alsancak M, Doğanay E, Karataş E, Davut Çapar I, Ertas $\mathrm{H}$. Cyclic fatigue analysis of Reciproc R25 $\AA$ instruments with different kinematics. Aust Endod J. 2016 Apr;42(1):22-4. https://doi.org/10.1111/aej.12115
117. Elsaka SE, Elnaghy AM, Badr AE. Torsional and bending resistance of waveone gold, reciproc and twisted file adaptive instruments. Int Endod J. 2017 Nov;50(11):1077-83. https://doi.org/10.1111/iej.12728

118. Özyürek T, Gündoğar M, Yılmaz K, Uslu G. Bending resistance and cyclic fatigue life of reciproc blue, waveone gold, and genius files in a double (S-shaped) curved canal. J Dent Res Dent Clin Dent Prospect. 2017;11(4):241-6. https://doi.org/10.15171/joddd.2017.042

119. Cavalli D, Toia CC, Flores Orozco El, Khoury RD, Cardoso FG, Alves $M C$ et al. Effectiveness in the removal of endotoxins and microbiological profile in primary endodontic infections using 3 different instrumentation systems: a randomized clinical study. J Endod. 2017 Aug;43(8):123745. https://doi.org/10.1016/i.joen.2017.03.032

120. Karataş E, Arslan H, Kırıcı DÖ, Alsancak M, Çapar ID. Quantitative evaluation of apically extruded debris with Twisted File Adaptive instruments in straight root canals: reciprocation with different angles, adaptive motion and continuous rotation. Int Endod J. 2016 Apr;49(4):382-5. https://doi.org/10.1111/iej.12461

121. Gergi R, Osta N, Bourbouze G, Zgheib C, Arbab-Chirani $R$, Naaman A. Effects of three nickel titanium instrument systems on root canal geometry assessed by microcomputed tomography. Int Endod J. 2015 Feb;48(2):162-70. https://doi.org/10.1111/iej.12296

122. Çapar ID, Arslan H. A review of instrumentation kinematics of engine-driven nickel-titanium instruments. Int Endod J. 2016 Feb;49(2):119-35. https://doi.org/10.1111/iej.12432

123. Peters $O A$, Arias A, Paqué F. A micro-computed tomographic assessment of root canal preparation with a novel instrument, TRUShape, in mesial roots of mandibular molars. J Endod. 2015 Sep;41(9):1545-50. https://doi.org/10.1016/i.joen.2015.06.007

124. Zuolo ML, Zaia AA, Belladonna FG, Silva EJ, Souza EM, Versiani MA et al. Micro-CT assessment of the shaping ability of four root canal instrumentation systems in ovalshaped canals. Int Endod J. 2018 May;51(5):564-71. https://doi.org/10.1111/iej.12810

125. Bortoluzzi EA, Carlon D Jr, Meghil MM, El-Awady AR, Niu L, Bergeron $\mathrm{BE}$, et al. Efficacy of $3 \mathrm{D}$ conforming nickel titanium rotary instruments in eliminating canal wall bacteria from oval-shaped root canals. J Dent. 2015 May;43(5):597-604. https://doi.org/10.1016/i.jdent.2015.01.001

126. Peters $O A$, Boessler C, Paqué F. Root canal preparation with a novel nickel-titanium instrument evaluated with micro-computed tomography: canal surface preparation over time. J Endod. 2010 Jun;36(6):1068-72. https://doi.org/10.1016/i.joen.2010.02.023

127. Metzger Z, Teperovich E, Zary R, Cohen R, Hof R. The self-adjusting file (SAF). Part 1: respecting the root canal anatomy: a new concept of endodontic files and its implementation. J Endod. 2010 Apr;36(4):679-90. https://doi.org/10.1016/i.joen.2009.12.036 
128. Lopes HP, Elias CN, Siqueira JF Jr, Soares RG, Souza LC, Oliveira JC, et al. Mechanical behavior of pathfinding endodontic instruments. J Endod. 2012 Oct;38(10):1417-21. https://doi.org/10.1016/i.joen.2012.05.005

129. Bürklein S, Benten S, Schäfer E. Shaping ability of different single-file systems in severely curved root canals of extracted teeth. Int Endod J. 2013 Jun;46(6):590-7. https://doi.org/10.1111/iej.12037

130. Peters OA, Peters $\mathrm{Cl}$, Schönenberger K, Barbakow F. ProTaper rotary root canal preparation: effects of canal anatomy on final shape analysed by micro CT. Int Endod J. 2003 Feb;36(2):86-92. https://doi.org/10.1046/j.1365-2591.2003.00626.x

131. Patiño PV, Biedma BM, Liébana CR, Cantatore G, Bahillo $J G$. The influence of a manual glide path on the separation rate of NiTi rotary instruments. J Endod. 2005 Feb;31(2):1146. https://doi.org/10.1097/01.don.0000136209.28647.13

132. Kim Y, Love R, George R. Surface Changes of PathFile after Glide Path Preparation: An Ex Vivo and In Vivo Study. J Endod. 2017 Oct;43(10):1674-8. https://doi.org/10.1016/i.joen.2017.04.008

133. Capar ID, Kaval ME, Ertas H, Sen BH. Comparison of the cyclic fatigue resistance of 5 different rotary pathfinding instruments made of conventional nickel-titanium wire, M-wire, and controlled memory wire. J Endod. 2015 Apr;41(4):535-8. https://doi.org/10.1016/i.joen.2014.11.008 134. Berutti E, Cantatore G, Castellucci A, Chiandussi G, Pera F, Migliaretti $G$ et al. Use of nickel-titanium rotary PathFile to create the glide path: comparison with manual preflaring in simulated root canals. J Endod. 2009 Mar;35(3):408-12. https://doi.org/10.1016/i.joen.2008.11.021
135. Nakagawa RK, Alves JL, Buono VT, Bahia MG. Flexibility and torsional behaviour of rotary nickel-titanium PathFile, $\mathrm{RaCe}$ ISO 10, Scout RaCe and stainless steel K-File hand instruments. Int Endod J. 2014 Mar;47(3):290-7. https://doi.org/10.1111/iej.12146

136. Alovisi M, Cemenasco A, Mancini L, Paolino D, Scotti N, Bianchi CC et al. Micro-CT evaluation of several glide path techniques and ProTaper Next shaping outcomes in maxillary first molar curved canals. Int Endod J. 2017 Apr;50(4):38797. https://doi.org/10.1111/iej.12628

137. Paleker F, van der Vyver PJ. Glide path enlargement of mandibular molar canals by using k-files, the proglider file, and g-files: a comparative study of the preparation times. J Endod. 2017 Apr;43(4):609-12. https://doi.org/10.1016/i.joen.2016.11.025

138. Elnaghy AM, Elsaka SE. Evaluation of the mechanical behaviour of PathFile and ProGlider pathfinding nickeltitanium rotary instruments. Int Endod J. 2015 Sep;48(9):894901. https://doi.org/10.1111/iej.12386

139. Ajuz NC, Armada L, Gonçalves LS, Debelian G, Siqueira Junior JF. Glide path preparation in S-shaped canals with rotary pathfinding nickel-titanium instruments. J Endod. 2013 Apr;39(4):534-7. https://doi.org/10.1016/i.joen.2012.12.025

140. Uslu G, Özyürek T, Yılmaz K, Gündoğar M. Cyclic fatigue resistance of R-Pilot, HyFlex EDM and PathFile nickeltitanium glide path files in artificial canals with double (S-shaped) curvature. Int Endod J. 2018 May;51(5):584-9. https://doi.org/10.1111/iej.12846

141. Metzger Z. The self-adjusting file (SAF) system: an evidencebased update. J Conserv Dent. 2014 Sep;17(5):401-19. https://doi.org/10.4103/0972-0707.139820 